Federal Reserve Bank of Minneapolis

Research Department Staff Report 429

July 2009

\title{
Larger Crises, Slower Recoveries The Asymmetric Effects of Financial Frictions *
}

\author{
Guillermo L. Ordoñez
}

Federal Reserve Bank of Minneapolis and Yale University

\begin{abstract}
It is well known that movements in lending rates are asymmetric; they rise quickly and sharply, but fall slowly and gradually. Not known is the fact that the asymmetry is stronger the less developed a country's financial system is. This new fact is here documented and explained in a model with an endogenous flow of information about economic conditions. The stronger asymmetry in less developed countries stems from their greater financial system frictions, such as monitoring and bankruptcy costs, which first magnify jumps of lending rates and then delay their recoveries by restricting the generation of information after the crisis. A quantitative exploration of the model shows the data are consistent with this explanation.
\end{abstract}

*E-mail: guillermo.ordonez@yale.edu. I thank Andy Atkeson, Ariel Burstein, V.V. Chari, Steve Durlauf, Christian Hellwig, Narayana Kocherlakota, David Lagakos, David K. Levine, Hanno Lustig, Stijn van Nieuwerburgh, Laura Veldkamp and Mike Waugh for excellent suggestions. I also thank Kathy Rolfe and Joan Gieseke for editorial assistance and seminar participants at UCLA, the Minneapolis Fed, the University of Minnesota, the University of Wisconsin-Madison, the 2006 Econometric Society Summer Meeting (Minnesota), the 2006 SED Annual Meeting (Vancouver), the 2008 AAEP Meetings (Cordoba, Argentina), the 2008 LACEA-LAMES Meetings (Rio de Janeiro, Brazil), and the 2009 Conference on "Financial Frictions and Segmented Markets" at the UCSB for their comments. The usual waiver of liability applies. The views expressed herein are those of the author and not necessarily those of the Federal Reserve Bank of Minneapolis or the Federal Reserve System. 


\section{Introduction}

Asymmetry in the movement of lending rates is well known. They tend to rise quickly and sharply during crises, but fall slowly and gradually during recoveries. This pattern, which has been observed in most of the recent financial crises, ${ }^{1}$ has important real consequences since it generates financial distresses and an inefficient reallocation of resources out of productive opportunities during the time period lending rates delay to recover. ${ }^{2}$ Many studies have offered explanations for this asymmetry, ${ }^{3}$ but no one has yet examined related features systematically across countries. I do that here and discover a new fact: the asymmetry in the movements of lending rates is stronger the less developed a country's financial system is. More specifically, I show this stronger asymmetry in less financially developed countries stems from their greater financial system frictions, such as monitoring and bankruptcy costs.

I propose an explanation for this new fact based on the informational effects of financial frictions. To do this I take Veldkamp's (2005) endogenous information model, which delivers asymmetry of lending rates movements, and introduce financial frictions to show how they increase asymmetry.

In the model entrepreneurs can only start a venture by borrowing. Whether they borrow or not depends on applicable lending rates, which are decided by lenders based on their expectation of being in good times, where probabilities ventures fail and entrepreneurs default are low. This expectation is constructed using signals from previous ventures' results: the less the number of ventures that failed, the more likely the economy is in good times. In a setting without financial frictions, whether a venture succeeds or fails is perfectly observed. When lenders think the state is good, they charge low rates, there is a lot of borrowing and hence a large sample of observations. When the state changes to bad, all these signals allow lenders to easily deduce that conditions have changed and they raise rates quickly to account for the higher default probability. Contrarily, since in bad times borrowing is low, when the state

\footnotetext{
${ }^{1}$ During 1994, Mexican lending rates took just 4 months to rise 70 percentage points, but more than 30 months to return to their pre-crisis levels. In October 1997, Brazilian real lending rates rose from $71 \%$ to $98 \%$, and they took 10 months to return to pre-crisis levels. In Indonesia, the 8 months following the Asian crisis experienced a rise in real lending rates from $18 \%$ to $35 \%$, and they took 24 months to return to pre-crisis levels. During the first half of 1998, Russian real lending rates rose from $24 \%$ to $48 \%$, and they took 25 months to return to pre-crisis levels.

${ }^{2}$ See, for example, Bergoeing, Loayza, and Repetto (2004).

${ }^{3}$ Veldkamp (2005) uses a model of endogenous flow of information to explain the unconditional asymmetry on lending rates movements. The bulk of the literature has focused on explanations for asymmetry in stock markets. Banerjee (1992), Welch (1992) and Banerjee and Newman (1993) explain crashes as the result of herd behavior and information cascades. Jacklin, Kleidon, and Pfleiderer (1992), based on Glosten and Milgrom (1985), use a portfolio insurance model of stock market crashes. Allen, Morris, and Shin (2006) use an information-based model of bubbles. Zeira $(1994,1999)$ proposes models of informational overshooting to explain booms and crashes in stock prices. For a review of asymmetries in real economic variables, see Van Nieuwerburgh and Veldkamp (2006) and Jovanovic (2006).
} 
changes to good, the limited number of existing ventures offers few signals about the switch, lenders learn about it slowly and reduce rates gradually. This endogenous learning is what generates asymmetry in movements of lending rates.

To study the effect of financial development on asymmetry, I assume only borrowers know the result of a venture while lenders can only observe it at a positive cost. The asymmetric information introduces incentives for borrowers to renege from their loans, reporting the failure of successful ventures. The monitoring and bankruptcy costs lenders have to incur to motivate truth telling by borrowers constitute a measure of the degree of financial frictions in the system. These costs have two effects in lending rates movements when compared to the setting without financial frictions. First, since monitoring and bankruptcy are more frequent during bad times, when the economy leaves good times, lenders include these higher expected costs in the lending rates, magnifying their jump. Second, the higher lending rates in bad times reduce investment and the number of available signals, slowing down the learning that fuels recoveries when the economy returns to good times. These two effects generate faster, sharper jumps and slower, gradual drops in lending rates, hence more asymmetry when compared to an economy without financial frictions.

Numerical tests of the model show my explanation is not only qualitatively but also quantitatively consistent with the new fact. First, by simulating a calibrated version of the model I show that reasonable levels of monitoring and bankruptcy costs predict the differences of asymmetry observed across countries. Second, I show that one of the model's main predictions - countries with less-developed financial systems face higher levels of lending spreadsis also both qualitatively and quantitatively consistent with the data. Finally, using data from the United States, I show the plausibility of an endogenous information mechanism to explain the asymmetry in lending rates movements and its potential to create inefficiencies.

Overall, therefore, my study is an empirical (Section 2), theoretical (Section 3), and quantitative (Section 4) investigation of the effects of financial frictions on the asymmetry of movements in lending rates.

\section{A New Fact: Movements in Lending Rates Are More Asymmetric in Countries with Less-Developed Financial Systems}

I begin my study with an empirical investigation into the asymmetry of movements in real lending rates across countries with different levels of development in their financial systems. I demonstrate here that robust to many measures of financial development, I get the same result: a stronger degree of asymmetry in real lending rates movements among countries 
with less-developed financial systems. This is what I am calling the new fact throughout the rest of the paper.

I measure the asymmetry of movements in lending rates for each country by constructing the distribution of monthly log changes in these rates and computing its unconditional skewness,

$$
\text { Skewness }=\frac{T \sqrt{T-1}}{T-2} \frac{\left[\sum_{t=1}^{T}\left(x_{t}-\bar{x}\right)^{3}\right]}{\left[\sum_{t=1}^{T}\left(x_{t}-\bar{x}\right)^{2}\right]^{\frac{3}{2}}},
$$

where $T$ is the number of observations (number of months in the sample), $x_{t}=\ln \left(\rho_{t}\right)-$ $\ln \left(\rho_{t-1}\right), \rho_{t}$ is the real lending rate in period $t$ and $\bar{x}$ is the sample mean of the time series. If lending rates in a country are more likely to experience large jumps rather than large reductions of the same magnitude, the skewness of their log changes is positive. Furthermore, a stronger asymmetry is captured by a higher positive skewness.

I compute skewness using International Monetary Fund (IMF) monthly data on real lending rates from 1960 to 2008 , for 100 countries. ${ }^{4}$ All the countries I select fulfill two minimum requirements: Their data have more than 48 observations (4 years) and show a defined cyclical pattern. A list of all countries in the sample, their individual levels of skewness, and their classifications is in Appendix A.1.

\subsection{General Measures of Financial Development}

I start analyzing the relation between lending rates skewness and financial development by using standard and general measures of financial development. First, for each country, I use the sample average of its credit to the private sector as a percentage of GDP from the World Bank's World Development Indicators (WDI) database . As shown in Table 1, just regressing these two variables for different period samples (1960-1985 and 1985-2008) ${ }^{5}$ and different country samples (all countries and non-African countries) ${ }^{6}$ produces a statistically

\footnotetext{
${ }^{4}$ I use data from the IMF's International Financial Statistics (IFS) to obtain real lending rates by subtracting the Hodrick-Prescott trend of inflation (IFS figure $64 P . . Z F$...) from nominal lending rates (IFS figure $60 P$.. $Z F$...). Two caveats are relevant. First, I choose the H-P filter to deflate nominal rates in order to capture both backward and forward looking components in the formation of inflation expectations. The alternative use of ex-post real lending rates (using current inflation as a deflator) delivers similar results, but has the disadvantage of losing informative months with large unexpected inflation shocks when computing log changes. Second, even when the definition of lending rates is not exactly the same across countries, in all of them they represent "the bank rate that usually meets the short- and medium- term financing needs of the private sector." It is unlikely though that differences in this definition bias the measure of skewness, which is based on changes over time for a given country.

${ }^{5}$ Results naturally hold for the whole sample 1960-2008 as well.

${ }^{6}$ Since many African countries have high skewness levels, I restrict the sample in this particular way to confirm the relation is not just driven by African fixed effects.
} 
Table 1: Asymmetry of Lending Rates and Financial Development

\begin{tabular}{|l|c|c|c|c|}
\hline \multirow{2}{*}{$\begin{array}{l}\text { Dependent Variable } \\
\text { Lending rate skewness }\end{array}$} & \multicolumn{2}{|c|}{ All Countries } & \multicolumn{2}{c|}{ Non-African Countries } \\
\cline { 2 - 5 } Credit to Private Sector / GDP & $1960-1985$ & $1985-2008$ & $1960-1985$ & $1985-2008$ \\
& & & & \\
Constant & -0.036 & -0.023 & -0.043 & -0.017 \\
& $(0.014)^{* *}$ & $(0.005)^{* * *}$ & $(0.017)^{* *}$ & $(0.005)^{* * *}$ \\
\hline Observations & 4.86 & 2.66 & 5.36 & 2.14 \\
& $(0.72)^{* * *}$ & $(0.42)^{* * *}$ & $(1.07)^{* * *}$ & $(0.48)^{* * *}$ \\
\hline
\end{tabular}

Notes: * Significant at $10 \%,{ }^{* *}$ significant at $5 \%$, and ${ }^{* *}$ significant at $1 \%$. Robust standard errors are reported in parentheses. The dependent variable is the skewness measured over the distribution of log changes in monthly lending rates, obtained from the IMF's IFS database. Yearly data on the credit to private sector as a percentage of GDP from the World Bank's WDI database. The simple average per country over the period sample is considered.

significant negative relationship in all cases. These results remain when controlling by the volatility of GDP per capita, the volatility of lending rates, and the average inflation.

Second, I classify countries into groups strongly correlated with financial development (see Levine (1997)) and compute the average lending rate skewness for each group. I classify countries by four development-related characteristics:

- Level of domestic income per capita. I use the World Bank's WDI classification, where the richest countries belong to group 1 and the poorest countries belong to group 4 .

- Membership or not to the OECD.

- Level of contract enforcement. I classify countries between those with low and high contract enforcement using the contract enforcement indicator of Levine, Loayza, and Beck (2000), which is an average between rule of law (an assessment of the law and order tradition of the country) and government risk (an assessment of the risk that the government will modify a contract after it has been signed) from La Porta et al. (1998). In both cases, the indices go from 1 (the lowest possible level) to 10 (the highest possible level). I use 5 as the relevant cutoff to separate countries evenly between the two groups.

- Availability of information in the financial system. I classify countries between those with and without a private bureau, defined by Djankov, McLiesh, and Shleifer (2007) as a private commercial firm or nonprofit organization that maintains a database on the standing of borrowers in the financial system and facilitates the exchange of information among banks and financial institutions. ${ }^{7}$

\footnotetext{
${ }^{7}$ Similar results hold when using the existence of either public or private bureau from Djankov et al. (2008).
} 
Table 2: Average Asymmetry of Lending Rates by Country Classification

\begin{tabular}{|l|c|c|c|}
\hline Country Classification & $1960-1985$ & $1985-2008$ & $\mathbf{1 9 6 0 - 2 0 0 8}$ \\
\hline Income group 1 (richest) & 2.71 & 0.28 & $\mathbf{1 . 5 4}$ \\
Income group 2 & 3.17 & 1.55 & $\mathbf{1 . 7 2}$ \\
Income group 3 & 4.22 & 1.77 & $\mathbf{2 . 0 8}$ \\
Income group 4 (poorest) & 4.87 & 2.91 & $\mathbf{3 . 3 3}$ \\
\hline OECD & 2.48 & 0.87 & $\mathbf{1 . 7 5}$ \\
Non-OECD & 4.36 & 1.98 & $\mathbf{2 . 4 6}$ \\
\hline High contract enforcement & 2.11 & 0.45 & $\mathbf{1 . 3 6}$ \\
Low contract enforcement & 4.17 & 2.44 & $\mathbf{2 . 9 2}$ \\
\hline Private bureau & 2.03 & 0.87 & $\mathbf{1 . 4 0}$ \\
No private bureau & 5.16 & 2.25 & $\mathbf{2 . 6 6}$ \\
\hline
\end{tabular}

Notes: Income classifications from the World Bank (WDI). Contract enforcement indicator from Levine, Loayza, and Beck (2000). Existence of a private bureau from Djankov, McLiesh, and Shleifer (2007). Asymmetry by group is the simple average of the skewness of member countries for the considered period.

In Table 2, I show simple averages of skewness across countries belonging to each group for the whole sample and also for two subperiods. ${ }^{8}$ Richer countries, OECD countries, and countries with good contract enforcement and information flows show on average less asymmetry than their counterparts (poorer countries, non-OECD countries, and countries with bad contract enforcement and information flows). This evidence reinforces the initial conclusion of a negative relation between asymmetry of changes in lending rates and financial development.

The table is also informative about asymmetry differences across countries. Since skewness numbers are difficult to interpret, I translate them as the number of months lending rates take to recover after a single one-month $10 \%$ jump, assuming the rate of decrease is constant in those months. The skewness corresponding to the first two income groups (1.54 and 1.72), for example, represents recoveries that take 2 or 3 months; in the third group recoveries take 6 months; and in the poorest group recoveries take 15 months.

\subsection{Specific Measures of Financial Development: Financial Frictions}

Now I study the relation between lending rates skewness and financial development by using more specific measures of financial development, in particular those related to financial frictions such as monitoring and bankruptcy costs. I perform this analysis both across countries and over time for a given country.

\footnotetext{
${ }^{8}$ In Appendix A.3, I repeat this exercise following two alternative approaches to measure skewness. In the first approach, I obtain skewness in log deviations from trend rather than in log changes. In the second approach, I obtain skewness in log changes of lending spreads with respect to 3-month Treasury bills (a standard measure of the risk-free interest rate) rather than levels. Results for both cases are consistent with those in Table 2.
} 


\subsubsection{Financial frictions across countries}

Comparable data on monitoring and bankruptcy costs across countries are not available. In fact, even estimations of these costs for the United States are subjects of a great controversy (Carlstrom and Fuerst (1997)). As an alternative I use two datasets as proxies. One is based on the work of Djankov et al. (2008), ${ }^{9}$ who approximate bankruptcy costs by surveying insolvency practitioners about the monetary and time costs of closing businesses in different countries. The other dataset is based on the work of Porter et al. (1999), who study how costly it is to monitor borrowers by analyzing the performance of financial and banking systems in improving information access and quality.

\section{a) Bankruptcy costs (Djankov et al. (2008)) ${ }^{10}$}

- Cost of bankruptcy: The total cost of a bankruptcy proceeding (in percentage of the estate value), which includes court/bankruptcy authorities costs, attorney fees, bankruptcy administrator fees, notification and publication fees, asset storage and preservation costs, auctioneer fees, government levies and other associated insolvency costs.

- Time for bankruptcy: The number of years required on average to complete a bankruptcy proceeding.

- Recovery rate: A measure of foreclosure efficiency. The recovery rate shows how many cents on the dollar claimants (creditors, tax authorities, and employees) recover from an insolvent firm. The calculation takes into account whether the business is kept as a going concern during the proceeding, the discounted value due to the time spent closing down, court costs, attorneys, and so on.

Table 3 shows the results of simple ordinary least squares (OLS) regressions between lending rates skewness and these measures. The positive relationship between bankruptcy costs and asymmetry (as seen in positive coefficients for cost and time of bankruptcy and negative for recovery rate of claimants) is statistically significant in all cases. Since Djankov et al. (2008) variables are measured for 2004, I also report results restricting the sample to $1985-2008$. The coefficients are basically the same and confirm the robustness of our results: lending rates movements in less financially developed countries are more asymmetric.

\footnotetext{
${ }^{9}$ When information was not available from Djankov et al. (2008), I completed it with data from Doing Business, Djankov et al. (2005).

${ }^{10}$ It is worth mentioning Djankov et al. (2008) constructed this dataset based on multiple-choice surveys to insolvency practitioners in different countries, not by a direct measure of bankruptcy costs.
} 
Table 3: Asymmetry of Lending Rates and Bankruptcy Costs

\begin{tabular}{|c|c|c|c|c|c|c|}
\hline $\begin{array}{l}\text { Dependent Variable } \\
\text { Lending Rate Skewness }\end{array}$ & \multicolumn{3}{|c|}{$1960-2008$} & \multicolumn{3}{|c|}{$1985-2008$} \\
\hline Cost of bankruptcy & $\begin{array}{c}0.037 \\
(0.012)^{* * *}\end{array}$ & & & $\begin{array}{c}0.044 \\
(0.012)^{* * *}\end{array}$ & & \\
\hline Time for bankruptcy & & $\begin{array}{c}0.221 \\
(0.100)^{* *}\end{array}$ & & & $\begin{array}{c}0.210 \\
(0.116)^{*}\end{array}$ & \\
\hline Recovery rate & & & $\begin{array}{c}-0.014 \\
(0.007)^{* *}\end{array}$ & & & $\begin{array}{c}-0.019 \\
(0.009)^{* * *}\end{array}$ \\
\hline Constant & $\begin{array}{c}1.265 \\
(0.322)^{* * *}\end{array}$ & $\begin{array}{c}1.252 \\
(0.347)^{* * *}\end{array}$ & $\begin{array}{c}2.356 \\
(0.398)^{* * *}\end{array}$ & $\begin{array}{c}0.668 \\
(0.294)^{* *}\end{array}$ & $\begin{array}{c}0.806 \\
(0.382)^{* *}\end{array}$ & $\begin{array}{c}2.047 \\
(0.407)^{* * *}\end{array}$ \\
\hline Observations & 85 & 85 & 85 & 85 & 85 & 85 \\
\hline
\end{tabular}

Notes: * Significant at $10 \%,{ }^{* *}$ significant at $5 \%$, and ${ }^{* * *}$ significant at $1 \%$. Robust standard errors are reported in parentheses. All independent variables are from Djankov et al. (2008) and Djankov et al. (2005).

\section{b) Monitoring costs (Porter et al. (1999))}

\section{- Legal protection for financial assets}

\section{- Sophistication of financial markets}

\section{- Availability of Internet banking}

\section{- Health of banking systems}

These monitoring costs variables are measured by an index that ranges from 1 to 7 (from the worst to the best). Table 4 shows the results of running simple OLS regressions of skewness on these variables: negative and statistically significant coefficients in all cases. The general conclusion is, again, that a more difficult flow of information in a financial system, and hence more financial frictions and less financial development, increases the asymmetry of movements in lending rates. By space considerations I report the regressions only for the more recent period 1985 - 2008 (the study Porter et al. (1999) is more relevant for the latest years). The regression results for the full sample 1960 - 2008 are almost identical.

\subsubsection{Financial frictions over time}

Given the high correlation across countries between the development of the financial system and the development in other sectors of the economy, more asymmetry in lending rates movements may be related to less development in those other sectors. An alternative way to test 
Table 4: Asymmetry of Lending Rates and Monitoring Costs

\begin{tabular}{|c|c|c|c|c|}
\hline \multirow{2}{*}{$\begin{array}{l}\text { Dependent Variable } \\
\text { Lending Rate Skewness }\end{array}$} & \multicolumn{4}{|c|}{$1985-2008$} \\
\hline & $\begin{array}{c}-0.71 \\
(0.24)^{* * *}\end{array}$ & & & \\
\hline Sophistication of financial markets & & $\begin{array}{c}-0.62 \\
(0.19)^{* * *}\end{array}$ & & \\
\hline Availability of Internet banking & & & $\begin{array}{c}-0.57 \\
(0.24)^{* *}\end{array}$ & \\
\hline Health of banking systems & & & & $\begin{array}{c}-0.56 \\
(0.16)^{* * *}\end{array}$ \\
\hline Constant & $\begin{array}{c}4.55 \\
(1.40)^{* * *}\end{array}$ & $\begin{array}{c}3.61 \\
(0.98)^{* * *}\end{array}$ & $\begin{array}{c}3.43 \\
(1.21)^{* * *}\end{array}$ & $\begin{array}{c}3.82 \\
(0.98)^{* * *}\end{array}$ \\
\hline Observations & 56 & 56 & 56 & 56 \\
\hline
\end{tabular}

Notes: * Significant at $10 \%,{ }^{* *}$ significant at $5 \%$, and ${ }^{* *}$ significant at $1 \%$. Robust standard errors are reported in parentheses. All independent variables were obtained from surveys conducted by Porter et al. (1999).

the importance of the financial development in the reduction of asymmetry is to analyze the evolution of lending rates skewness in a given country over time.

First, technology improvements are closely related to financial system developments, since financial frictions are based on the efficiency of auditing accounts and on the ease of sharing and transmitting information. That is, the better the available technology (such as computers and telecommunications) is in a country, the lower the monitoring and bankruptcy costs within its financial sector (Merton (1987)). Information technologies have improved significantly and continuously from 1960 on. Table 2 shows that, for all classification groups, asymmetry in lending rates decreases over time, maintaining the ranking among them. A plausible interpretation is that technological improvements reduce financial frictions and asymmetry over time in all countries.

Second, we compare skewness in a given country before and after a financial liberalization process. This process is a shock that abruptly reduces monitoring and bankruptcy costs, and in general financial frictions, by opening the system to competition and by inducing the adoption of modern and more efficient practices, a better enforcement of contracts, and easier flow of information. This test, too, supports the new fact of negative relation between asymmetry and financial development.

Data on financial liberalization are obtained from Kaminsky and Schmukler (2008) for the period 1973 - 2005. Their work includes information on liberalization along three dimensions: capital accounts, domestic financial sectors, and stock market capitalization. Capital 
account liberalization refers to an increased ability of corporations to borrow abroad and fewer controls on exchange rate mechanisms and other sorts of capital. Domestic financial liberalization refers to a loosening of interest rate controls (lending and deposits) and other restrictions, such as directed credit policies or limitations on foreign currency deposits. Stock market liberalization refers to an increase in the degree to which foreigners are allowed to own domestic equity and a decrease in restrictions to repatriate capital, dividends, and interests. I focus on 16 countries for which I have enough data to reliably measure skewness before and after major liberalization events (more than 47 observations on each side).

Table 5 shows a comparison of lending rates skewness for each country before and after its main financial liberalization event. ${ }^{11}$ For all the countries, except Ireland, lending rate skewness raised after their main liberalization event. Table 6 shows a comparison of skewness for each country before and after its whole financial liberalization process, while Table 7 shows the same comparison before and after a financial restriction process. ${ }^{12}$ Of the 16 countries, only Korea did not experience a reduction in skewness after liberalization. In contrast, the three countries that restricted the financial system experienced an increase in skewness after that process. All these results are also consistent with the new fact.

To conclude, regardless of which indicator is examined as a measure of financial development - standard such as credit to the private sector as a percentage of GDP and enforcement of contracts, or more specific measures of financial frictions, both across countries or over time, such as bankruptcy costs, monitoring costs, health or sophistication of financial markets, the historical evolution of technology for all countries, or financial liberalization processes - the indicator supports the documented relationship between the degree of asymmetry of movements in real lending rates and the degree of financial development.

\section{The Model}

My empirical analysis has generated a new fact. But it has also strongly suggested an explanation for that fact. The specific measures of financial development, which capture financial frictions through bankruptcy and monitoring costs, seem particularly relevant in explaining differences of lending rates asymmetry across countries. Therefore, I here provide a model

\footnotetext{
${ }^{11}$ The main financial liberalization event is defined as occurring in the month in which the maximum number of liberalization changes have been introduced into the financial system. I do not report results for Chile, Indonesia, and Thailand because their financial systems experienced both liberalization and restriction processes during the sample period 1973-2005.

${ }^{12}$ The financial liberalization process is defined as the time frame between the first liberalization change and the last one during the sample 1973-2005. A financial restriction process is identically defined. Since Chile, Indonesia, and Thailand experienced both liberalization and restriction processes, I can here analyze their experiences.
} 
Table 5: Asymmetry of Lending Rates before and after the Main Financial Liberalization Event

\begin{tabular}{|c|c|c|c|c|c|}
\hline \multirow[t]{3}{*}{ Country } & \multirow{2}{*}{\multicolumn{2}{|c|}{$\begin{array}{c}\text { Main Financial } \\
\text { Liberalization Event }\end{array}$}} & \multirow{3}{*}{$\begin{array}{c}\text { Type of } \\
\text { Liberalization }\end{array}$} & \multicolumn{2}{|c|}{ Skewness } \\
\hline & & & & \multirow[t]{2}{*}{ Before } & \multirow[t]{2}{*}{ After } \\
\hline & Month & Year & & & \\
\hline Canada & March & 1975 & KA & 0.88 & 0.41 \\
\hline Finland & January & 1990 & SM and DFS & 0.43 & 0.13 \\
\hline France & January & 1985 & DFS and KA & 3.94 & 0.05 \\
\hline Ireland & January & 1992 & SM and DFS & 0.57 & 0.95 \\
\hline Italy & January & 1992 & KA & 0.63 & 0.60 \\
\hline Japan & January & 1985 & SM & 1.95 & -0.30 \\
\hline Korea & January & 1999 & SM & -0.10 & -0.27 \\
\hline Philippines & January & 1994 & KA and SM & 0.37 & 0.17 \\
\hline Portugal & January & 1986 & SM & 4.05 & -0.33 \\
\hline Spain & December & 1992 & KA & 2.09 & 0.48 \\
\hline Sweden & January & 1984 & KA & 3.48 & 0.02 \\
\hline UK & October & 1973 & KA & 3.91 & 1.49 \\
\hline Venezuela & April & 1996 & SM & 3.75 & 0.32 \\
\hline
\end{tabular}

Notes: KA stands for Capital Account, SM stands for Stock Market, and DFS stands for Domestic Financial System. Data on liberalization dates are from Kaminsky and Schmukler (2008).

Table 6: Asymmetry of Lending Rates before and after a Financial Liberalization Process

\begin{tabular}{|c|c|c|c|c|c|c|}
\hline \multirow[t]{3}{*}{ Country } & \multirow{2}{*}{\multicolumn{2}{|c|}{$\begin{array}{c}\text { Start of Financial } \\
\text { Liberalization Process }\end{array}$}} & \multirow{2}{*}{\multicolumn{2}{|c|}{$\begin{array}{c}\text { End of Financial } \\
\text { Liberalization Process }\end{array}$}} & \multicolumn{2}{|c|}{ Skewness } \\
\hline & & & & & \multirow[t]{2}{*}{ Before } & \multirow[t]{2}{*}{ After } \\
\hline & Month & Year & Month & Year & & \\
\hline Canada & March & 1975 & March & 1975 & 0.88 & 0.41 \\
\hline Chile & January & 1984 & September & 1998 & 1.17 & -0.15 \\
\hline Finland & January & 1986 & January & 1990 & 1.83 & 0.13 \\
\hline France & January & 1985 & January & 1990 & 3.94 & 0.08 \\
\hline Indonesia & January & 1983 & August & 1989 & 1.38 & 0.95 \\
\hline Ireland & May & 1985 & January & 1992 & 1.82 & 0.95 \\
\hline Italy & May & 1987 & January & 1992 & 1.42 & 0.60 \\
\hline Japan & January & 1979 & December & 1991 & 1.64 & -1.39 \\
\hline Korea & January & 1988 & January & 1999 & -0.58 & -0.27 \\
\hline Philippines & January & 1976 & January & 1994 & 8.04 & 0.17 \\
\hline Portugal & January & 1976 & August & 1992 & 4.60 & -0.09 \\
\hline Spain & January & 1981 & December & 1992 & 2.22 & 0.48 \\
\hline Sweden & January & 1978 & January & 1989 & 3.76 & 0.68 \\
\hline Thailand & January & 1979 & June & 1992 & 1.81 & 0.13 \\
\hline UK & October & 1973 & January & 1981 & 3.91 & 2.00 \\
\hline Venezuela & April & 1996 & April & 1996 & 3.75 & 0.32 \\
\hline
\end{tabular}

Note: Data on liberalization dates are from Kaminsky and Schmukler (2008). 
Table 7: Asymmetry of Lending Rates before and after a Financial Restriction Process

\begin{tabular}{|c|c|c|c|c|c|c|}
\hline \multirow[t]{3}{*}{ Country } & \multirow{2}{*}{\multicolumn{2}{|c|}{$\begin{array}{c}\text { Start of Financial } \\
\text { Restriction Process }\end{array}$}} & \multirow{2}{*}{\multicolumn{2}{|c|}{$\begin{array}{c}\text { End of Financial } \\
\text { Restriction Process }\end{array}$}} & \multicolumn{2}{|c|}{ Skewness } \\
\hline & & & & & \multirow[t]{2}{*}{ Before } & \multirow[t]{2}{*}{ After } \\
\hline & Month & Year & Month & Year & & \\
\hline Chile & June & 1979 & January & 1983 & 0.66 & 1.17 \\
\hline Indonesia & March & 1991 & March & 1991 & 0.95 & 5.32 \\
\hline Thailand & August & 1995 & May & 1997 & 0.13 & 0.81 \\
\hline
\end{tabular}

Note: Data on restriction dates are from Kaminsky and Schmukler (2008).

in order to be able to theoretically and quantitatively test these frictions as an explanation for the new fact.

\subsection{An Overview}

The model I use is a modified version of Veldkamp's (2005) endogenous information model, in which I include financial frictions, more specifically monitoring and bankruptcy costs. I show these frictions restrict the flow of information about the state of the economy more after crises than before crises, hence delaying recoveries and magnifying crises. Here I summarize the main features of both models.

In the frictionless Veldkamp's (2005) model, entrepreneurs should borrow to invest in a risky venture. Lending rates are based on lenders' inferences about an unobserved state of the economy that drives failure probabilities (a good state is one with low failure probability, and hence low default probability). This inference is constructed using signals from previous ventures' results, all of which are perfectly observed. When lenders think the state of the economy is good, lending rates are low and there is a large number of ventures in the economy, which generates a large number of signals about that state. When the state changes to bad, all those signals allow lenders to easily recognize that conditions have changed, so lending rates rise quickly and sharply to account for the higher failure probability. When the state is bad and changes to good, however, the limited number of existing ventures generates few signals about the change, so lenders learn about it slowly, and lending rates drop slowly and gradually.

Into this setup, I introduce an informational friction - an asymmetric amount of information between borrowers and lenders - so that the observation of the signals to infer the state of the economy is no longer costless to lenders. To motivate truth-telling by borrowers, lenders should sometimes spend to monitor the success of ventures by taking defaulting ones to bankruptcy. Hence monitoring and bankruptcy costs are a representation of the frictions. 
Monitoring and bankruptcy costs have two effects. One is to lower the number of signals available in the economy, since with higher lender costs come higher lending rates and less economic activity. That effect is not symmetric across economic states. In times with a high probability of venture failure, monitoring and bankruptcy are more common and the costs induce an increase in rates and restrictions on loans, slowing the creation of new economic activity and so reducing the number of signals available to lenders. Contrarily, when the probability of failure is low these costs are irrelevant to the level of economic activity. Monitoring and bankruptcy costs thus slow the learning that fuels recoveries from crises but not the information that sustains crises. The other effect of monitoring and bankruptcy costs is to increase jumps in lending rates when failure rates increase, which magnifies crises. Together, these two effects result in quicker, sharper rises and slower, more gradual falls in lending rates, hence more asymmetry in their movements in countries with larger frictions.

\subsection{Formal Description}

My model, like Veldkamp's (2005), has a credit market with a finite number $N$ of risk-neutral entrepreneurs without funds on their own and $M$ perfectly competitive and risk-neutral investors, each which has one indivisible unit of capital, where $N<M$. As in Veldkamp's model, some of these entrepreneurs borrow to start a venture, hence some of the investors are lenders. Unlike Veldkamp's model, my model has asymmetric information between borrowers and lenders.

In each period $t$, each entrepreneur $i$ observes a business opportunity that pays $v_{i t}$ (drawn from a support $(\underline{v} ; \bar{v}))$ in case of success ${ }^{13}$ and zero otherwise. All ventures require the same initial investment (normalized to 1). If entrepreneurs decide to undertake the venture, they must borrow the money. If they decide not to borrow, their only option is to work for an exogenously fixed wage $w$. Investors can either lend the indivisible unit of capital to entrepreneurs or invest it in a riskless bond that pays an exogenous and constant rate $1+r$.

In this economy, the probability of success is the same for all ventures in period $t, \theta_{g}$ in good times $(G)$ and $\theta_{b}$ in bad times $(B)$, where $\theta_{g}>\theta_{b}$ and $G$ and $B$ are the only two possible states of an aggregate variable that follows a Markov process with persistence $1-\lambda$. I assume that neither borrowers nor lenders can observe the state of the economy when negotiating a loan, but both try to infer it from observations of venture realizations in the previous period.

More explicitly, the expected probability of success of a venture in period $t+1$ is determined in the following way. From the $n_{t}$ funded ventures in period $t$, agents observe a number of successes $\left(s_{t}\right)$ and form posterior beliefs $\mu_{t}^{P}$, using Bayes' rule and a prior $\mu_{t}=\operatorname{Pr}(G)_{t}:{ }^{14}$

\footnotetext{
${ }^{13}$ This support does not include trivial agents who always invest or never invest.

${ }^{14}$ Recall that $C_{s}^{n}=C_{n-s}^{n}=n ! /[(n-s) ! s !]$ and then $C_{s}^{n}$ drops from the equation.
} 


$$
\mu_{t}^{P}=\operatorname{Pr}\left(G \mid s_{t}\right)_{t}=\frac{\theta_{g}^{s_{t}}\left(1-\theta_{g}\right)^{n_{t}-s_{t}} \mu_{t}}{\theta_{g}^{s_{t}}\left(1-\theta_{g}\right)^{n_{t}-s_{t}} \mu_{t}+\theta_{b}^{s_{t}}\left(1-\theta_{b}\right)^{n_{t}-s_{t}}\left(1-\mu_{t}\right)} .
$$

Adjusting these posteriors by the probability of a change in state, the probability of being in a good state in $t+1$ is

$$
\mu_{t+1}=\operatorname{Pr}(G)_{t+1}=(1-\lambda) \mu_{t}^{P}+\lambda\left(1-\mu_{t}^{P}\right)
$$

And finally, the expected probability of success of a given venture in $t+1$ is

$$
\theta_{t+1}=\operatorname{Pr}(s)_{t+1}=\mu_{t+1} \theta_{g}+\left(1-\mu_{t+1}\right) \theta_{b}
$$

When the loan is negotiated between an entrepreneur $i$ and an investor $j$, the venture's potential payoff $v_{i t}$ is observable ex ante by both, but the lender can observe ex post whether the borrower was successful or not, only at a positive cost $c$. At the end of the period, borrowers may pay the stipulated lending rate to lender $j,\left(1+\rho_{j t}\right)$, or default. Depending on this action, the lender spends $c$ to monitor the result or not, following the specifications of the contract by taking the borrower to bankruptcy. Hence, I assume full commitment.

It is worth highlighting at this point that $c$ represents both the monitoring and bankruptcy costs required to overcome the financial friction of asymmetric information between borrowers and lenders, hence being a measure of the development of the financial system in the economy.

In summary, the timing of the model in each period $t$ is as follows:

- Entrepreneurs and investors agree on their beliefs of being in a good state $\left(\mu_{t}\right)$.

- Investors offer a loan contract, taking into account the monitoring and bankruptcy costs c. Entrepreneurs decide whether or not to borrow and start a venture given those contracts. Entrepreneurs not borrowing work in a job that pays $w$. Investors not lending invest in a riskless bond that pays $1+r$.

- Production occurs. A borrower receives cash flows when its venture is successful.

- Borrowers report the result of their ventures to lenders, and contracts are fulfilled. All reports and monitoring results are publicly observed.

- Beliefs about the probability of being in a good state in the next period $\left(\mu_{t+1}\right)$ are updated. The state changes with a probability $\lambda$. 


\subsection{Equilibrium Outcomes}

Here I define and characterize the equilibrium in this model. Even when we obtain an explicit analytical solution in each period, it is not possible to express the dynamics of the model explicitly. However, the nature of the equilibrium allows us to discuss the effects of financial frictions on the asymmetry of movements in lending rates.

Definition 1 A subgame perfect Nash equilibrium (SPNE), for an initial belief $\mu_{0}$, is given by time sequences of borrowing $\left(b_{i t}\right)$ and payment decisions in case of success $\left(z_{i t}\right)$ by each entrepreneur $i$, lending rates $\left(\rho_{i j t}\right)$ and monitoring decisions $\left(\gamma_{j t}\right)$ by each investor $j$, and Bayesian beliefs about the probability of being in a good state $\mu_{t}$, such that the following problems are solved in each period $t$ :

- Each entrepreneur i maximizes expected utility:

$$
\max _{b_{i t} \in\{0,1\} ; z_{i t} \in[0,1] ; j \in\{1, \ldots, M\}} b_{i t} \theta_{t}\left\{z_{i t}\left[v_{i t}-\left(1+\rho_{i j t}\right)\right]+\left(1-z_{i t}\right)\left(1-\gamma_{j t}\right) v_{i t}\right\}+\left(1-b_{i t}\right) w
$$

where $\theta_{t}=\mu_{t} \theta_{g}+\left(1-\mu_{t}\right) \theta_{b}$ is the expected probability of a successful venture, which depends on the expected state of the economy.

- Each investor $j$ maximizes expected profits:

$$
\max _{\rho_{i j t} \in \mathbb{R}, \gamma_{j t} \in\{0,1\}} l_{j t} \theta_{t}\left\{z_{i t}\left(1+\rho_{i j t}\right)+\left(1-z_{i t}\right) \gamma_{j t}\left(v_{i t}-c\right)\right\}-l_{j t} \gamma_{j t}\left(1-\theta_{t}\right) c+\left(1-l_{j t}\right)(1+r),
$$

where $l_{j t}=1$ if some borrower decides to take a loan from this investor in period $t .{ }^{15}$

- Beliefs are updated using Bayes' rule, following equations (2), (3), and (4), where the total number of ventures funded is $n_{t}=\sum_{i=1}^{N} b_{i t}$.

The following proposition characterizes the unique SPNE with nonstochastic monitoring, which takes the form of an optimal standard debt contract.

Proposition 2 In each period $t$, in equilibrium, all investors $j$ set the same lending rate $1+\rho_{t}=$ $\frac{1+r}{\theta_{t}}+\frac{\left(1-\theta_{t}\right)}{\theta_{t}} c$ to all borrowers $i$ and monitor every default $\left(\gamma_{j t}=1\right)$. All entrepreneurs $i$ borrow $\left(b_{i t}=1\right)$ from any lender $j$ whenever $v_{i t} \geq \widetilde{\nu}_{t}=\frac{1}{\theta_{t}}\left[1+r+w+\left(1-\theta_{t}\right) c\right]$. All borrowers report the truth $\left(z_{i t}=1\right)$.

\footnotetext{
${ }^{15}$ Recall that I'm not allowing mixing strategies in monitoring decisions (that is, $\gamma_{j t} \in\{0,1\}$ rather than $\gamma_{j t} \in$ $[0,1])$. I focus on nonstochastic monitoring just for expositional reasons, since it is cleaner to highlight the effects of monitoring costs on asymmetry. In Appendix A.4, I describe the optimal equilibrium with stochastic monitoring and discuss why the results in terms of the asymmetry impact of $c$ are sustained.
} 
Proof. First I describe the debt contract that investors offer. Then, I discuss entrepreneurs' actions under this contract.

Step 1: Investor's choice

As in Townsend (1979) and Gale and Hellwig (1985), here the standard debt contract is optimal under costly state verification with nonstochastic monitoring. In my setting, this result is even more trivial, since the cash flow for successful ventures is known and only the failure event is unknown. If lenders do not monitor a default, then borrowers always default, in which case lenders would not lend. Hence, $\gamma_{j t}=1$. Since investors are competitive, expected profits from lending should equalize expected profits from the riskless bond $1+r$,

$$
\left(1-\theta_{t}\right)(-c)+\theta_{t}\left(1+\rho_{i j t}\right)=1+r
$$

Since the expected probability of success is the same for all ventures and the above condition is independent of the cash flow of a given venture $v_{i t}$, all investors $j$ choose to charge the same lending rates to all entrepreneurs $i$ (that is, $\rho_{i j t}=\rho_{t}$ for all $i$ and all $j$ ).

$$
\left(1+\rho_{t}\right)=\frac{1+r}{\theta_{t}}+\frac{\left(1-\theta_{t}\right)}{\theta_{t}} c
$$

\section{Step 2: Entrepreneur's choice}

Since lending rates are the same across lenders, borrowers are indifferent about which lender $j$ they borrow from. Given the previous contract, successful borrowers always prefer to repay the loan $\left(z_{i t}=1\right)$, obtaining $\nu_{i t}-\left(1+\rho_{t}\right)>0$ rather than 0 if defaulting. The only choice left to obtain in equilibrium is whether entrepreneurs borrow or not (that is, $b_{i t} \in\{0,1\}$ ). This choice is given by a cutoff value over $v_{i t}$ such that an entrepreneur $i$ borrows in period $t$ whenever $\theta_{t}\left[v_{i t}-\left(1+\rho_{t}\right)\right] \geq w$. From equation (5) it is clear that $b_{i t}=1$

$$
v_{i t} \geq \widetilde{\nu}_{t}=\frac{1}{\theta_{t}}\left[1+r+w+\left(1-\theta_{t}\right) c\right]
$$

A key variable is the number of ventures $n_{t}$ funded in the economy since it determines the number of signals available for agents to update beliefs. In equilibrium this number is given by the sum of entrepreneurs who borrow in period $t$.

$$
n_{t}=\sum_{i \in\{1, \ldots, N\}} \mathbf{1}_{\left\{v_{i t} \geq \widetilde{\nu}_{t}=\frac{1}{\theta_{t}}\left[1+r+w+\left(1-\theta_{t}\right) c\right]\right\}},
$$


where $\mathbf{1}$ is an indicator function that adopts the number 1 when the condition in brackets (equation 6) is fulfilled and 0 otherwise.

The number of ventures depends positively on the probability of success $\theta_{t}$ in two ways: a higher $\theta_{t}$ increases expected profits; and a higher $\theta_{t}$ decreases market lending rates $\rho$, directly by decreasing the probability of default and indirectly by reducing expected monitoring costs. Formally, $\frac{\partial \widetilde{\nu}_{t}}{\partial \theta_{t}}=-(1+r+w+c) / \theta_{t}^{2}<0 .{ }^{16}$ More interestingly, since $\theta_{t}$ increases with the probability of being in a good state $\mu_{t}$,

$$
\frac{\partial \widetilde{\nu}_{t}}{\partial \mu_{t}}=-\left(\theta_{g}-\theta_{b}\right) \frac{[1+r+w+c]}{\left(\mu_{t} \theta_{g}+\left(1-\mu_{t}\right) \theta_{b}\right)^{2}}<0
$$

This is important for the determination of signals in the economy. The greater the value for $\mu_{t}$, the greater is $\theta_{t}$, the lower the borrowing cutoff value $\widetilde{\nu}_{t}$ and the more the number of funded ventures.

At this point, I need to analyze more specifically my addition of monitoring and bankruptcy costs $c$ into Veldkamp's (2005) model. I here note three effects. First, when it is costless for lenders to monitor ventures' results $(c=0)$, this solution coincides with Veldkamp's original one. Second, when monitoring costs $c$ are positive, they increase lending rate levels and cutoffs $\widetilde{\nu}_{t}$, thus reducing the number of funded ventures in all states. Formally,

$$
\frac{\partial \widetilde{\nu}_{t}}{\partial c}=\frac{\partial\left(1+\rho_{t}\right)}{\partial c}=\frac{1-\theta_{t}}{\theta_{t}}>0
$$

Third, this reduction in ventures is not constant across states, since $\theta_{t}$ affects lending rates non-linearly. As $\theta_{t}$ varies, $c$ is scaled by a double effect in the numerator $\left(1-\theta_{t}\right)$ and the denominator $\left(\theta_{t}\right)$.

Figure 1 shows the model's relation between lending rates $\left(1+\rho_{t}\right)$ and the expected probability of success $\left(\theta_{t}\right)$ for a given level of monitoring and bankruptcy costs $c$. When the market believes the probability of success is very high, lenders assign a low probability of having to spend on bankruptcy at the end of the period, then monitoring and bankruptcy costs do not impose serious restrictions on lending rates and signals. Contrarily, when the market believes the probability of success is low, lenders assign a high probability to having to spend on monitoring and bankruptcy at the end of the period, and these costs have a large role in the determination of lending rates and the number of signals.

Since the number of signals is changing continuously, writing an explicit analytical solution of the dynamic evolution of lending rates is intractable. This dynamic behavior is discussed later by using Monte Carlo simulations.

\footnotetext{
${ }^{16} \mathrm{~A}$ smaller $\widetilde{\nu}_{t}$ strictly implies higher $n_{t}$ whenever the density function has mass at all points $v_{i} \in(\underline{v} ; \bar{v})$.
} 
Figure 1: Lending Rates and the Expected Probability of Success

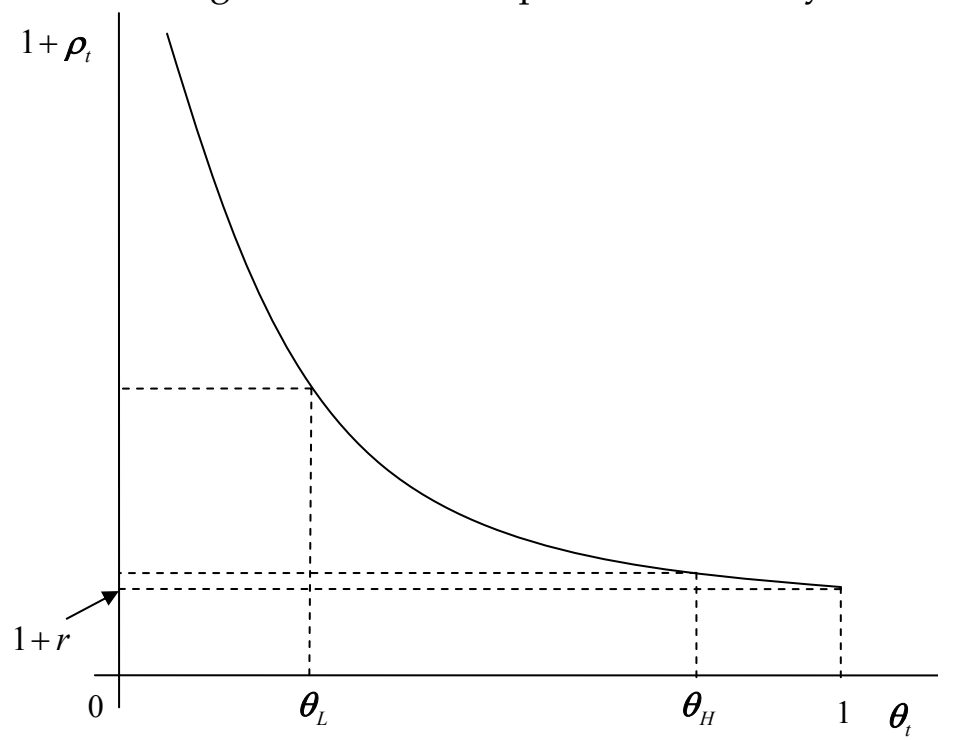

\subsection{Asymmetry Implications}

Despite the intractability of the model's dynamic solution, I can discuss analytically what is of primary interest here: the model's implications for asymmetry in lending rates movements. I demonstrate that the financial frictions I have introduced impede the flow of information more after crises than before them, increasing the asymmetry in lending rates movements and implying the new fact.

The following proposition shows that monitoring and bankruptcy costs increase the unconditional skewness on the distribution of lending rate changes. The first part of the proof sketches out why endogenous information generates asymmetry in the first place, by making lending rates time-irreversible. I just add this part for self-containment reasons, an input to understand the effects of financial frictions on asymmetry. Veldkamp (2005) contains the full-fledged formal proof of lending rates time-irreversibility in a frictionless framework.

Proposition 3 In an endogenous information economy, monitoring and bankruptcy costs increase the asymmetry of movements in lending rates measured by their unconditional skewness.

Proof. The proof proceeds in three steps. First, I introduce the concept of time-reversibility and explain the symmetric nature of lending rates in a constant information economy. Second, I sketch out why lending rates are time-irreversible and asymmetric in an endogenous information economy. Finally, I show that monitoring and bankruptcy costs increase the asymmetry of movements in lending rates. 
Step 1: Time-reversibility in a constant information economy

Time-reversibility is defined as the property of a stochastic process in which it is not possible to determine, given the states at a number of points in time after running the stochastic process, which states came first and which states arrived later. In our case beliefs of being in good times are time reversible if their increase when all signals are positive has the same magnitude as their decrease when all signals are negative. Assume that the prior of a good state is $\mu_{t}=x$. If all $n_{t}$ ventures fail $\left(s_{t}=0\right)$, then $\mu_{t+1}=y<x$. If in the next period all $n_{t+1}$ ventures succeed $\left(s_{t+1}=n_{t+1}\right)$ and the process is time-reversible, then $\mu_{t+2}=z=x$ and it is not possible to tell the order of successes and failures.

In a constant information economy, the number of signals $n$ is given exogenously. Without loss of generality, assume the economy has equally informative signals $\left(\theta=\theta_{g}=1-\theta_{b}>\frac{1}{2}\right)$ and no state change $(\lambda=0) .{ }^{17}$ If initial beliefs in period $t$ are $\mu_{t}=x$ and all $n$ signals fail $(s=0)$, then from equations (2) and (3) we know that

$$
\mu_{t+1}=y=\frac{(1-\theta)^{n} x}{(1-\theta)^{n} x+\theta^{n}(1-x)} .
$$

If in the next period $t+1$ all $n$ signals are successful $(s=n)$, then

$$
\mu_{t+2}=z=\frac{\theta^{n} y}{\theta^{n} y+(1-\theta)^{n}(1-y)} .
$$

Replacing (9) with (10), gives $\mu_{t+2}=z=x$. Hence, in a constant information economy, beliefs follow a time-reversible stochastic process.

Step 2: Time-irreversibility in an endogenous information economy

In an endogenous information economy, the number of signals depends on the beliefs of being in a good state. A higher probability of being in good times $\mu_{t}$ represents a lower cutoff $\widetilde{\nu}_{t}$ and more signals $n_{t}$. In this framework, beliefs are no longer time-reversible. Assume that in period $t, \mu_{t}=x$ and all $n_{t}^{x}$ signals fail $\left(s_{t}=0\right)$. The subscript $t$ is now necessary because $n$ varies with time and the superscript $x$ because $n_{t}$ depends on beliefs $\mu_{t}=x$. Then

$$
\mu_{t+1}=y=\frac{(1-\theta)^{n_{t}^{x}} x}{(1-\theta)^{n_{t}^{x}} x+\theta^{n_{t}^{x}}(1-x)} .
$$

Now, given that $y<x$, agents are less confident about being in good times, which reduces the number of ventures, $n_{t+1}^{y}<n_{t}^{x}$. Assume that in the following period, all $n_{t+1}^{y}$ signals are

\footnotetext{
${ }^{17}$ As shown by Veldkamp (2005), the logic of the proof extends to not equally informative signals and $\lambda>0$.
} 
successful $^{18}\left(s_{t+1}=n_{t+1}^{y}\right)$. Then

$$
\mu_{t+2}=z=\frac{\theta^{n_{t+1}^{y}} y}{\theta^{n_{t+1}^{y}} y+(1-\theta)^{n_{t+1}^{y}}(1-y)} .
$$

Now replacing (11) with (12) gives that

$$
\mu_{t+2}=z=\frac{\left[\theta^{n_{t+1}^{y}}(1-\theta)^{n_{t}^{x}}\right] x}{\left[\theta^{n_{t+1}^{y}}(1-\theta)^{n_{t}^{x}}\right] x+\left[(1-\theta)^{n_{t+1}^{y}} \theta^{n_{t}^{x}}\right](1-x)}
$$

and we can compute

$$
z-x=\frac{\left[\theta^{n_{t+1}^{y}}(1-\theta)^{n_{t}^{x}}-(1-\theta)^{n_{t+1}^{y}} \theta^{n_{t}^{x}}\right] x(1-x)}{\left[\theta^{n_{t+1}^{y}}(1-\theta)^{n_{t}^{x}}\right] x+\left[(1-\theta)^{n_{t+1}^{y}} \theta^{n_{t}^{x}}\right](1-x)} .
$$

It is straightforward to check that $z<x$ as long as $\theta>\frac{1}{2}$ and $n_{t+1}^{y}<n_{t}^{x}$. This means that the greatest possible decrease in beliefs (from $x$ to $y$ ) is more likely than an increase of the same magnitude (since beliefs just go from $y$ to $z$ ). Given equation (5), the greatest possible increase in lending rates is more likely than a decrease of the same magnitude, which is a necessary and sufficient condition for the existence of positive unconditional asymmetry in lending rates. Hence, in an endogenous information economy, beliefs follow a time-irreversible stochastic process that translates into a positive asymmetry in lending rates changes.

\section{Step 3: The effect of monitoring and bankruptcy costs on asymmetry}

First, for a country with a given $c$, we take the difference between the maximum possible increase in lending rates and the maximum possible decrease in lending rates. These two numbers are the extremes of the two tails in the distribution of lending rates changes. The larger the difference between them, the larger the average unconditional skewness of the distribution. Then we compare this difference across countries with different levels of $c$.

Changes in lending rates are proportional to changes in beliefs $\theta_{t}$, which are proportional to the number of signals or the cutoffs $\widetilde{\nu}\left(\theta_{t}\right)$. Hence the difference between the maximum possible increase and the maximum possible decrease in lending rates is proportional to $\widetilde{\nu}\left(\theta_{b}\right)-\widetilde{\nu}\left(\theta_{g}\right)$. A large difference means that the number of ventures when lenders are pessimistic (at $\theta_{b}$ ) is much lower than the number of ventures when lenders are optimistic (at $\left.\theta_{g}\right)$, and hence that the maximum possible decrease in lending rates (from $\theta_{b}$ ) is much lower than the maximum possible increase in lending rates (from $\theta_{g}$ ).

\footnotetext{
${ }^{18}$ The same conclusion is obtained when reversing the order of successes and failures.
} 
Computing the difference in cutoffs,

$$
\widetilde{\nu}\left(\theta_{b}\right)-\widetilde{\nu}\left(\theta_{g}\right)=\frac{\left(\theta_{g}-\theta_{b}\right)}{\theta_{g} \theta_{b}}[1+r+w+c]>0 .
$$

Taking derivatives with respect to $c$

$$
\frac{\partial\left(\widetilde{\nu}\left(\theta_{b}\right)-\widetilde{\nu}\left(\theta_{g}\right)\right)}{\partial c}=\frac{\left(\theta_{g}-\theta_{b}\right)}{\theta_{g} \theta_{b}}>0
$$

it can be seen that the difference between the maximum possible increase and decrease of lending rates raises with monitoring costs $c$ hence higher $c$ increases the unconditional lending rates skewness in average. Also, the impact of monitoring costs is bigger as $\theta_{b}$ goes to zero.

Finally, recall that, conditional on a reduction of beliefs of a given magnitude, two countries with the same lending rate but different levels of monitoring costs will experience an increase in lending rates,

$$
\frac{\partial\left(1+\rho_{t}\right)}{\partial \theta_{t}}=-\frac{1+r+c}{\theta_{t}^{2}}<0
$$

but the increase is larger in the country with higher monitoring costs, magnifying the crisis, since,

$$
\frac{\partial\left|\frac{\partial\left(1+\rho_{t}\right)}{\partial \theta_{t}}\right|}{\partial c}=\frac{1}{\theta_{t}^{2}}>0 .
$$

This magnification effect of $c$ on the rise in lending rates increases also the conditional skewness of changes in lending rates.

My proof of Proposition 3 shows that countries with higher monitoring and bankruptcy costs experience larger increases and slower decreases of lending rates. This translates into the new fact: a greater asymmetry of movements in lending rates for countries with greater frictions, or less-developed financial systems.

The intuition for this result is captured by Figure 2, which compares Figure 1 for two countries with different monitoring and bankruptcy costs. The first panel of Figure 2 shows the crisis magnification force of monitoring costs. A given decrease in the expected probability of venture success generates a greater jump of lending rates in countries with higher monitoring costs. The second panel of Figure 2 shows the recovery delaying force of monitoring costs. The gap between lending rates in countries with different monitoring costs widens as the expected probability of venture success decreases. This implies that the speed of recoveries after 
bad times differs between the two countries more than the speed of crises after good times.

Figure 2: Monitoring Costs Magnify Crises and Delay Recoveries

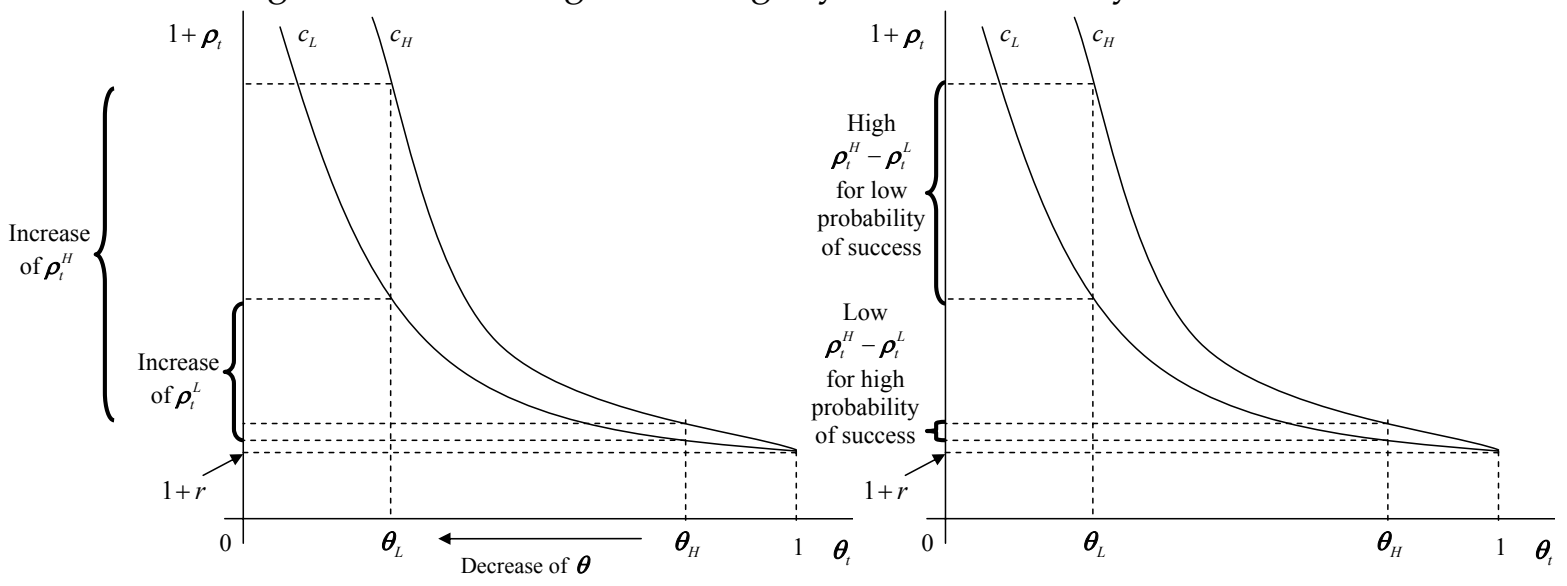

\section{Quantitative Tests}

Now I perform some quantitative tests of my model. First, I calibrate the model and, by simulating it, I show that for reasonable levels of monitoring and bankruptcy costs, it predicts the differences of skewness observed across countries. Second, I show that one of the model's main predictions - countries with less-developed financial systems have higher levels of lending spreads - is both qualitatively and quantitatively consistent with the data. Finally, using data from the United States, I test the plausibility of endogenous information to explain asymmetry of lending rates and its potential effects on inefficiency.

\subsection{Simulations}

Now I use the model to test quantitatively my explanation for the new fact. A calibrated version of the model shows that plausible differences of monitoring and bankruptcy costs across countries can explain their differences in asymmetry of movements in lending rates.

\section{a. The Parameters}

To calibrate my endogenous information model, I use the parameter values used by Veldkamp (2005): $\theta_{g}=0.97, \theta_{b}=0.95, \lambda=0.027, r=0.0042, w=1$ and $N=25$. 
The probabilities of a venture's success $\left(\theta_{g}\right.$ and $\left.\theta_{b}\right)$ are calibrated using bond default rates listed by Moody's for 1970 - 2000. Main results use the probabilities of success of U.S. speculative grade bonds, which are riskier than typical U.S. corporate bonds since information on default rates of emerging market bonds is unavailable. ${ }^{19}$ The probability of a state transition $\lambda$ is obtained using world GDP from the Penn World Tables. The largest potential number of independent observable signals $N$, was cleverly obtained by Veldkamp (2005) by measuring the speed of price adjustments in the United States. ${ }^{20}$ I assume venture profits are distributed uniformly in $[\underline{v}, \bar{v}]$, where $\underline{v}=\frac{1+w+r}{\bar{\theta}}$ and $\bar{v}=\frac{1+w+r}{\underline{\theta}}$, with $\bar{\theta}$ the most optimistic probability of success and $\underline{\theta}$ the most pessimistic one. ${ }^{21}$ Finally, parameters $r$ and $w$ only affect the scale of the lending rate, and skewness is invariant in scale. ${ }^{22}$ Although I use the same parameters to represent a whole array of countries, I will argue later that this is in fact a conservative exercise.

Using these parameters, I simulate lending rates for 1,000 periods and compute the unconditional skewness of their log changes. I repeat this simulation 10,000 times, obtaining Montecarlo standard deviations.

\section{b. Asymmetry Implications}

Now I display the relationship between financial frictions (measured by monitoring and bankruptcy costs, $c$ ) and the asymmetry of movements in lending rates that the calibrated model delivers.

Figure 3 shows skewness from the simulations and two standard deviations bounds for each level of monitoring costs. Since I assume that the initial investment for each venture is 1 , a monitoring cost of, for example $c=0.3$, represents a cost of $30 \%$ of the initial investment. As I have formally shown, monitoring costs increase the unconditional skewness of changes in lending rates. Furthermore, Monte Carlo standard errors show that differences in asymmetry caused by different monitoring costs are statistically significant at standard confidence levels. ${ }^{23}$

The result with complete information ( $c=0$ and skewness around 1.60) is consistent with

\footnotetext{
${ }^{19}$ For developed countries, I perform the exercise using information on "all corporate" bonds $\left(\theta_{b}=0.97\right.$ and $\left.\theta_{g}=0.98\right)$. Results are very similar.

${ }^{20}$ This parameter is very important, since it determines the speed at which the economy learns about the aggregate state. When $N$ goes to infinity, the economy learns immediately about the true state; hence, asymmetry is nonexistent. Since my main goal is to match differences across countries, an alternative way to calibrate $N$ is to match the skewness of developed countries (1.51) and use it for the rest of the countries. This alternative $N$ is just a little higher than Veldkamp's $(N=31)$, and results are almost identical.

${ }^{21}$ Results assuming a normal distribution with $95 \%$ in $[\underline{v}, \bar{v}]$ delivers similar results.

${ }^{22}$ Skewness is independent of $r$ and $w$ because the support for the distribution of $v_{i}$ is $[\underline{v}, \bar{v}]$.

${ }^{23}$ Even when the simulation results displayed here are based on pure monitoring strategies (consistent with the theoretical section), very similar results are obtained using the equilibrium based on random monitoring.
} 
Figure 3: Model's Simulated Lending Rate Skewness at Different Monitoring Costs

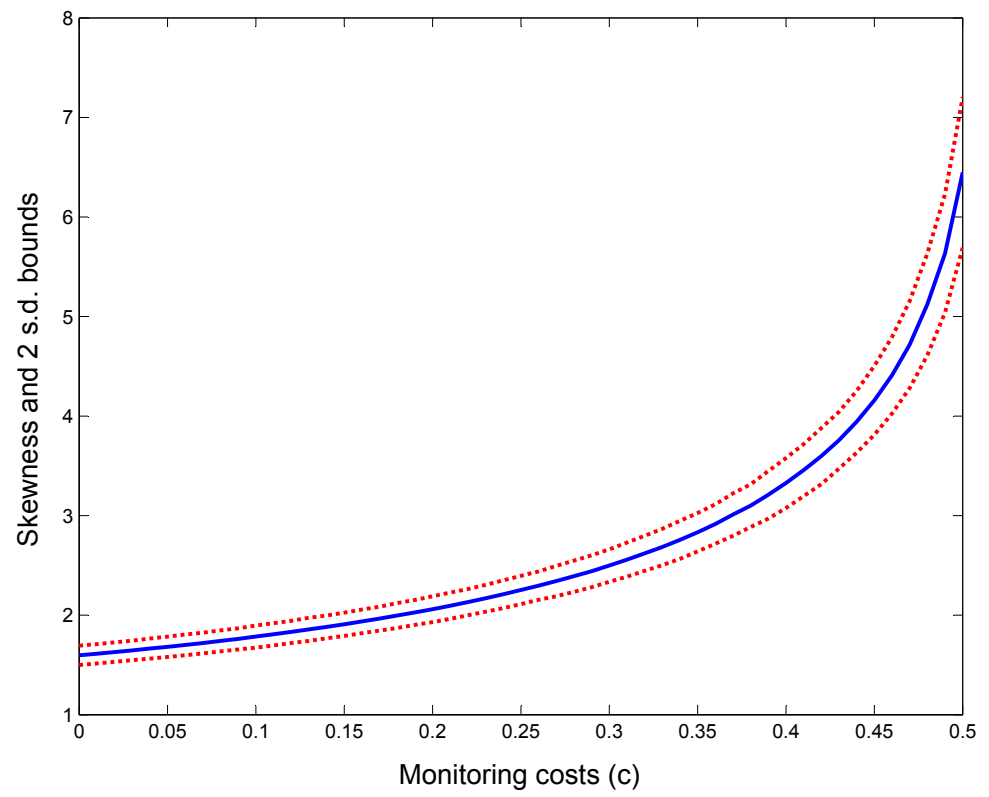

Veldkamp (2005) with uniformly distributed investment payoffs. This is an important benchmark to test the relevance of my explanation. For example, the skewness of 3.33 that developing countries show on average (income group 4 in Table 2) can be obtained at $c=0$ only if developing countries would be characterized by the following unrealistic conditions:

- Very stable states, $\lambda=0.0002$ (states change each 417 years).

- Very persistent bad times. If $\operatorname{Pr}(B \mid G)=\lambda=0.027$, then $\operatorname{Pr}(B \mid B)=0.998$ (bad states last 50 years in average).

- Clearer and extreme signals: If $\theta_{g}=0.97$, then $\theta_{b}=0.82$ (in bad times $18 \%$ of firms default). If $\theta_{b}=0.95$, then $\theta_{g}=0.995$ (in good times the probability of default is almost 0 , much less than in developed countries).

These are similar conditions Veldkamp (2005) identifies to match a skewness of 2.9 in 13 emerging countries she studies. In our case a skewness of 2.9 is consistent with bankruptcy costs of around $35 \%$ of initial investment, without the need to make dramatic changes to the calibrated parameters.

Now we can use the model to determine the magnitude of monitoring and bankruptcy costs that is consistent with the empirical skewness documented earlier (first column of Table 8) and to check if these numbers are plausible. The third column of Table 8 shows the model's 
Table 8: Implied Monitoring Costs to Match Data on Lending Rate Asymmetry

\begin{tabular}{|c|c|c|c|}
\hline Country Classification & $\begin{array}{c}\text { Data } \\
\text { Skewness }\end{array}$ & $\begin{array}{c}\text { Djankov et al. (2008) } \\
\text { Bankruptcy Costs }\end{array}$ & $\begin{array}{c}\text { Model's c } \\
\text { Range (in \%) }\end{array}$ \\
\hline Income group 1 (richest) & 1.54 & 7.2 & $0-4$ \\
\hline Income group 2 & 1.72 & 15.8 & $5-15$ \\
\hline Income group 3 & 2.08 & 16.6 & $18-24$ \\
\hline Income group 4 (poorest) & 3.33 & 24.4 & $38-42$ \\
\hline OECD & 1.75 & 8.8 & $5-15$ \\
\hline Non-OECD & 2.46 & 19.2 & $26-32$ \\
\hline High contract enforcement & 1.36 & 10.9 & 0 \\
\hline Low contract enforcement & 2.92 & 23.3 & $33-37$ \\
\hline Private bureau & 1.40 & 11.5 & $0-1$ \\
\hline No private bureau & 2.66 & 21.1 & $29-35$ \\
\hline
\end{tabular}

Notes: Country classification and data skewness columns are the first and fourth columns of Table 2. Bankruptcy costs are from Djankov et al. (2008). Consistent $c$ refers to monitoring costs that, given the parameters, allow us to match the skewness observed in data. The range is determined by two Monte Carlo standard deviations at each side of the point estimation.

range of monitoring and bankruptcy costs (based on two Monte Carlo standard deviations) that is consistent with skewness in each group.

In order to evaluate these numbers, I compare the costs implied by the model with the subjective measure of monitoring and bankruptcy costs offered by Djankov et al. (2008) (second column of Table 8). Even when the costs our model needs to explain the empirical differences of skewness are less concentrated than Djankov et al.'s estimated costs (in particular lower for developed and higher for developing countries), they are in line with those numbers. Hence, my model is also quantitatively consistent with the new fact.

\section{c. The Dynamic Nature of the Results}

Finally, to illustrate the nature of the results, Figure 4 shows an example of the model's view of lending rate dynamics under the same shock realizations but with different levels of monitoring costs-which, again, represent different levels of financial frictions or development of the financial system. More precisely, Figure 4 displays the paths of lending rates over 100 simulated periods (out of 1,000 periods) of 1 simulation (out of 10,000 simulations) for three economies with different levels of monitoring costs, $c=0, c=0.25$, and $c=0.5$.

This figure displays three clear relationships:

- Lending rates are higher in economies with higher monitoring and bankruptcy costs.

- When the economy moves from good times $(G)$ to bad times $(B)$, lending rates jump more in the countries with high costs than in the country without costs. 
Figure 4: Model's Evolution of Lending Rates with Different Levels of Monitoring Costs

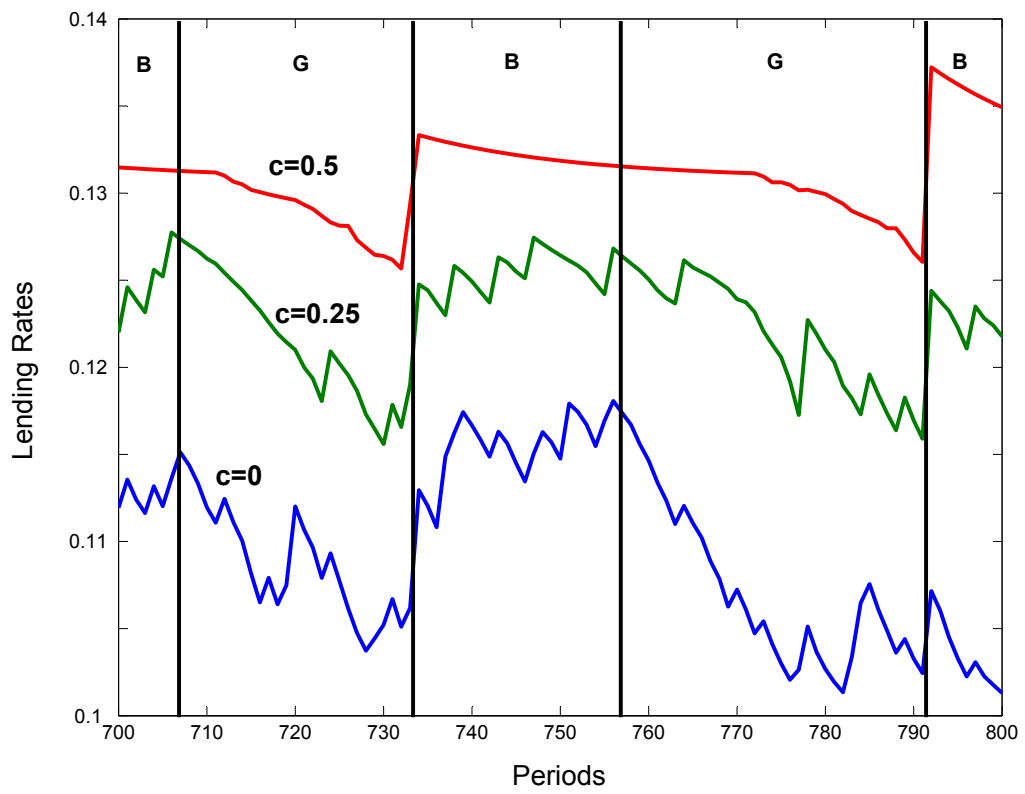

- When the economy moves from bad times $(B)$ to good times $(G)$, lending rates decline everywhere, but they are faster in the country without costs than in the countries with high costs.

Overall, then, this figure illustrates that higher monitoring costs (more relevant frictions) generate higher levels of lending rates, magnify crises, and delay the generation of signals that fuel recoveries. This is why the model produces a positive relationship between the asymmetry of movements in lending rates and monitoring and bankruptcy costs. Here, I have shown this relationship is not only qualitatively but also quantitatively correct.

\subsection{Testable Predictions about Levels of Lending Spreads}

The model generates testable predictions in terms of the level of lending spreads, measured as the difference between lending rates and risk-free interest rates: countries with less developed financial systems have, on average, higher lending spreads.

First, it is useful to decompose lending rates in the model (equation 5) in three terms: a riskfree rate, a risk premium (which depends on the risk-free rate adjusted by default probabilities), and expected monitoring and bankruptcy costs to solve the frictions imposed by asymmetric information, such that

$$
\rho_{t}=r+\frac{\left(1-\theta_{t}\right)}{\theta_{t}}(1+r)+\frac{\left(1-\theta_{t}\right)}{\theta_{t}} c
$$


Since $\frac{\partial\left(\rho_{t}-r\right)}{\partial c}=\left(1-\theta_{t}\right) / \theta_{t}>0$, spreads $\rho_{t}-r$ increase with monitoring and bankruptcy costs. Here we show not only this is the case empirically but also that the calibrated version of the model can explain quantitatively spread differences across countries.

\section{a. Monitoring Costs Increase Lending Spreads}

We construct lending spreads by taking the monthly difference between real lending rates and 3-month Treasury bill yields for each country. ${ }^{24}$ We then take the average spread for each country in the sample period 1960-2005.

Table 9 shows the results of running regressions between average levels of lending spreads and our general and specific measures of financial development. All coefficients have the expected sign and are statistically significant. An important drawback is that, unlike regressions to explain skewness, level comparison may be capturing important differences in methodologies and definitions across countries. Even when we have to be more careful in interpreting these regressions, results are robust to many sample restrictions and seem consistent with the prediction that monitoring and bankruptcy costs increase lending spreads.

\section{b. Monitoring Costs Are Quantitatively Important}

Here I show differences in monitoring costs are also quantitatively important to explain differences of lending spreads across countries.

The first column of Table 10 shows the average real lending rates for the country classifications defined earlier and the second column shows average lending spreads. While real lending rates among the poorest countries are roughly double than those among the richest countries, spreads more than double. In the third column I show simulated spreads from the calibrated version of the model. In the fourth and fifth columns I decompose spreads between risk premium (by using average 3-month Treasury bill yields for each country in the sample to calibrate risk-free rates) and financial frictions costs (by using the estimated monitoring and bankruptcy costs from the last column in Table 8).

Two conclusions can be drawn from Table 10. First, comparing data and simulated spreads (columns 2 and 3), the model matches spreads observed in developed countries and underestimates spreads in less developed countries. However, the differences are important, with spreads in poorest countries doubling those in richest countries. Second, as shown in the last column, monitoring costs account for more than $25 \%$ of spreads in developing countries (income group 4) and less than $2 \%$ in developed ones (income group 1). ${ }^{25}$

\footnotetext{
${ }^{24}$ The information on 3-month Treasury bill yields was obtained from the Global Financial Database (GFD) (2008). We have monthly data for 63 countries from 1960 to 2005.

${ }^{25}$ I have not found evidence of large cross-country differences in the volatility of log changes in lending rates. This is also consistent with the model, as shown in Appendix A.2.
} 
Table 9: Lending Rate Spreads and Financial Development

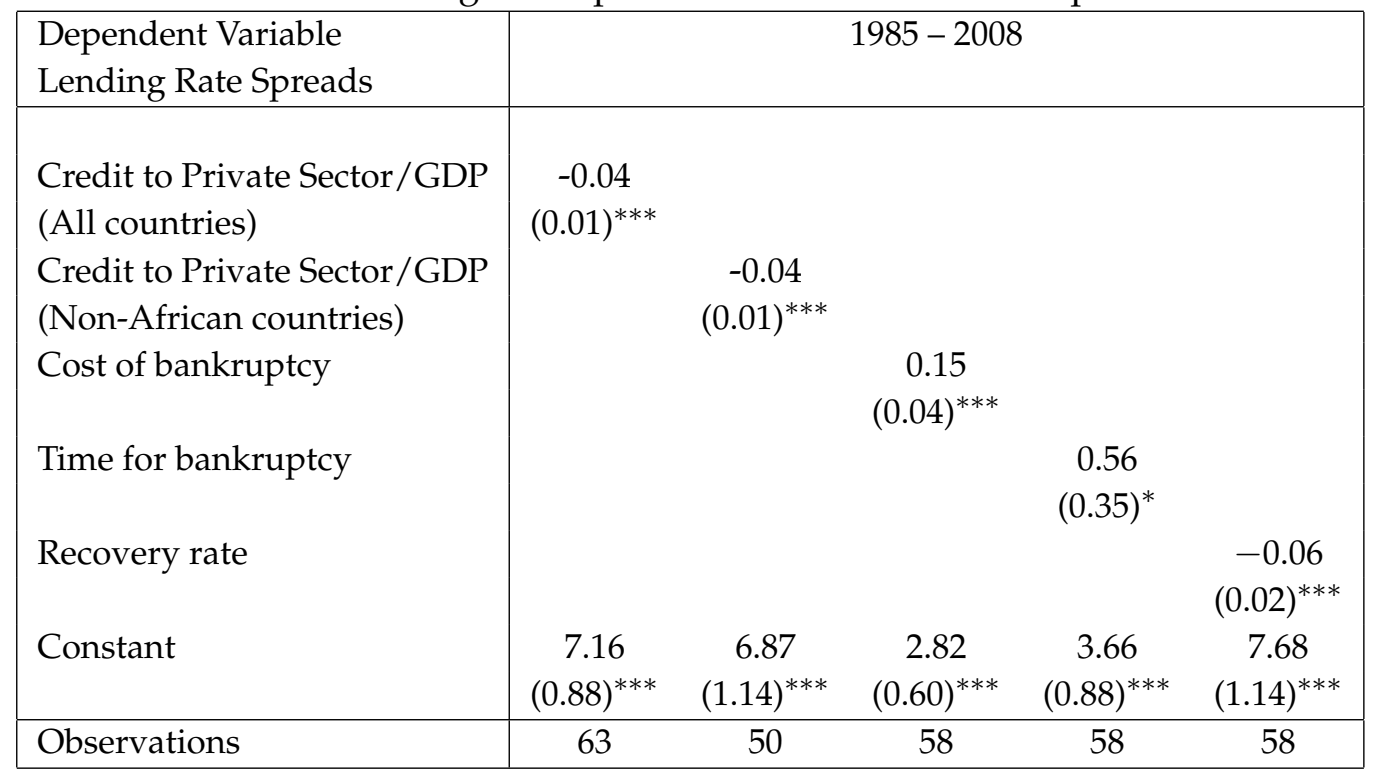

\begin{tabular}{|c|c|c|c|c|}
\hline \multirow{2}{*}{$\begin{array}{l}\text { Dependent Variable } \\
\text { Lending Rate Spreads } \\
\text { Legal protection to financial assets }\end{array}$} & \multicolumn{4}{|c|}{$1985-2008$} \\
\hline & $\begin{array}{c}-1.76 \\
(0.55)^{* * *}\end{array}$ & & & \\
\hline Sophistication for financial markets & & $\begin{array}{c}-1.41 \\
(0.47)^{* * *}\end{array}$ & & \\
\hline Availability of Internet banking & & & $\begin{array}{c}-1.19 \\
(0.48)^{* *}\end{array}$ & \\
\hline Health of banking systems & & & & $\begin{array}{c}-1.16 \\
(0.82)^{* *}\end{array}$ \\
\hline Constant & $\begin{array}{c}13.75 \\
(3.20)^{* * *}\end{array}$ & $\begin{array}{c}10.81 \\
(2.44)^{* * *}\end{array}$ & $\begin{array}{c}9.73 \\
(2.46)^{* * *} \\
\end{array}$ & $\begin{array}{c}10.59 \\
(2.83)^{* * *}\end{array}$ \\
\hline Observations & 43 & 43 & 43 & 43 \\
\hline
\end{tabular}

Notes: ${ }^{*}$ Significant at $10 \%,{ }^{* *}$ significant at $5 \%$, and ${ }^{* * *}$ significant at $1 \%$. Robust standard errors are reported in parentheses. 
Table 10: Data vs. Model Spreads of Lending Rates

\begin{tabular}{|c|c|c|c|c|c|c|}
\hline \multirow[t]{3}{*}{ Country Classification } & \multicolumn{2}{|c|}{ Data } & \multicolumn{4}{|c|}{ Model } \\
\hline & \multirow{2}{*}{$\begin{array}{c}\text { Lending } \\
\text { Rates }\end{array}$} & \multirow[t]{2}{*}{ Spread } & \multirow[t]{2}{*}{ Spread } & \multicolumn{2}{|c|}{ Components } & \multirow{2}{*}{$\begin{array}{c}\text { \% of Spread } \\
\text { c explains }\end{array}$} \\
\hline & & & & $\frac{(1-\theta)(1+r)}{\theta}$ & $\frac{(1-\theta)}{\theta} c$ & \\
\hline Income group 1 (richest) & 12.5 & 2.9 & 2.9 & 2.8 & 0.1 & 1.8 \\
\hline Income group 2 & 19.2 & 4.1 & 3.2 & 3.0 & 0.3 & 8.0 \\
\hline Income group 3 & 17.7 & 6.0 & 5.5 & 4.7 & 0.9 & 15.2 \\
\hline Income group 4 (poorest) & 20.3 & 7.9 & 6.4 & 4.7 & 1.7 & 26.2 \\
\hline OECD & 11.9 & 2.9 & 3.1 & 2.8 & 0.3 & 8.4 \\
\hline Non-OECD & 20.2 & 6.3 & 6.0 & 4.7 & 1.2 & 20.3 \\
\hline High contract enforcement & 14.9 & 3.2 & 2.9 & 2.9 & 0.0 & 0.0 \\
\hline Low contract enforcement & 18.4 & 6.0 & 6.1 & 4.7 & 1.5 & 23.7 \\
\hline Private bureau & 16.4 & 3.8 & 2.9 & 2.9 & 0.0 & 0.4 \\
\hline No private bureau & 19.7 & 6.9 & 6.0 & 4.7 & 1.3 & 22.1 \\
\hline
\end{tabular}

\subsection{Evidence of Endogenous Learning Mechanism in the United States}

In this subsection I tackle two questions related to our model.

First, is the asymmetry of lending rates just a reflection of asymmetry in fundamentals, in particular asymmetry in default probabilities? I show that in the United States changes in default probabilities are negatively, not positively, skewed. If lenders were learning fast about these probabilities, lending rates would follow them closer. One possibility for this inconsistency is that, as proposed in the paper, there are frictions for lenders to learn about real default probabilities.

Second, if learning is the right story, do the number of signals in the economy and the uncertainty recover slowly after a sudden decrease? We show that investment in the United States is negatively skewed (it decreases fast and recovers slowly) and uncertainty is positively skewed (it increases fast and recovers slowly), which is consistent with the mechanism proposed here.

The variables I use to answer these questions are as follows:

- Default probabilities: Moody's monthly trailing 12-month issuer default rate for all rated corporate bonds. Sample: 1970-2008.

- Uncertainty: Quarterly uncertainty index from Bloom, Floetotto, and Jaimovich (2009). This index combines spreads in the growth of firm sales and output, in firm stock returns, in forecaster predicted unemployment and industrial production, and volatilities 
in macro output growth and stock returns. Sample: 1962-I:2008-II. ${ }^{26}$

- Investment: Quarterly data of net borrowing from corporate business from the Flow of Funds Accounts of the United States published by the Federal Reserve Board. Sample: 1962-I:2008-II

As shown in Appendix A.1, log changes of real lending rates in the United States are positively skewed (0.31). ${ }^{27}$ Log changes of corporate default rates are negatively skewed (-1.72). Log changes of uncertainty are positively skewed $(0.83),{ }^{28}$ and log changes of investment are negatively skewed (-0.95).

All these results are consistent with the model. After a sudden increase in lending rates, investment declines and takes time for it to recover (negative skewness), making the uncertainty in the economy and hence lending rates to decline slowly (positive skewness). Since this asymmetric pattern of movements in lending rates does not reflect the evolution of real default probabilities (which are negative skewed) it generates an inefficient reallocation of resources out of productive activities during periods of time where default probabilities are in fact low, but lenders are not yet convinced and charge high rates.

\section{Conclusions}

A well-documented feature of lending rates is the asymmetry of their changes. In general, upturns are sudden and sharp, while downturns are slow and gradual. This is a non-trivial fact; the asymmetry may generate financial distresses and may eventually also affect the real economy by, for example, causing a costly reallocation of resources. Here I have documented a new, related fact: the well-known asymmetry is stronger the less developed the financial system of a country is.

My explanation for that fact relies on the greater amount of frictions, in particular monitoring and bankruptcy costs, in the financial systems of developing countries. I build this explanation into an endogenous model of information. The frictions not only magnify crises but also

\footnotetext{
${ }^{26}$ I do not include information after 2008-II, since it would capture a big uncertainty jump that would bias the skewness computations positively since the corresponding recovery has not yet been realized.

${ }^{27}$ This number is based on data from the IFS, which only has information on mortgage rates and prime rates for the United States. Since mortgage rates, which better represent the financial needs of the private sector, are only available from April 1971, we used prime rates for the sixties. An alternative series of real lending rates for the United States is constructed by Neely and Rapach (2008) with quarterly data from the Federal Reserve System from 1953 to 2007. Log changes in their real lending rate series have a skewness of 0.6.

${ }^{28}$ Alternatively I used the VIX Index from the CBOE, that uses option prices to determine the uncertainty in stock markets. The skewness of log changes is also positive (0.7).
} 
restrict the generation of information after crises and so lead to slower, more gradual recoveries in countries with less-developed financial systems. Simulations and other quantitative tests of the model are consistent with my explanation.

Here I have added elements to understand the effects of financial frictions beyond the welldocumented first-order effects of raising the cost of capital and decreasing the level of investment. I have shown that financial frictions also magnify crises and slow down recoveries generating potentially large inefficiencies in the reallocation of resources over the business cycle. Hence, this paper provides an additional reason to reduce monitoring and bankruptcy costs in financial systems and an additional source of gains from financial liberalization processes. 


\section{References}

Allen, Franklin, Stephen Morris, and Hyun Song Shin. 2006. "Beauty Contests and Iterated Expectations in Asset Markets." Review of Financial Studies 19:719-752.

Banerjee, Abhijit. 1992. "A Simple Model of Herd Behavior." Quarterly Journal of Economics 107:797-817.

Banerjee, Abhijit V., and Andrew F. Newman. 1993. "Occupational Choice and the Process of Development." Journal of Political Economy 101:274-298.

Bergoeing, Raphael, Norman Loayza, and Andrea Repetto. 2004. "Slow Recoveries." Journal of Development Economics 75:473-506.

Bloom, Nicholas, Max Floetotto, and Nir Jaimovich. 2009. "Really Uncertain Business Cycles." Mimeo, Stanford University.

Carlstrom, Charles, and Timothy Fuerst. 1997. "Agency Costs, Net Worth, and Business Fluctuations: A Computable General Equilibrium Analysis." American Economic Review 87:893-910.

Djankov, Simeon, Oliver Hart, Caralee McLiesh, and Andrei Shleifer. 2008. "Debt Enforcement around the World." Journal of Political Economy 116:1105-1149.

Djankov, Simeon, Oliver Hart, Tatiana Nenova, and Andrei Shleifer. 2005. "Efficiency in Bankruptcy." Working Paper, Department of Economics, Harvard University.

Djankov, Simeon, Caralee McLiesh, and Andrei Shleifer. 2007. "Private Credit in 129 Countries." Journal of Financial Economics 84:299-329.

Gale, Douglas, and Martin Hellwig. 1985. "Incentive-Compatible Debt Contracts: The OnePeriod Problem." Review of Economic Studies 52:647-663.

GFD. 2008. Global Financial Database. Global Financial Data. Online Database.

Glosten, Lawrence, and Paul Milgrom. 1985. “Bid, Ask and Transaction Prices in a Specialist Market with Heterogeneously Informed Traders." Journal of Financial Economics 14:71100.

IFS. 2008. International Financial Statistics. International Monetary Fund. Online Database. Jacklin, Charles, Allan Kleidon, and Paul Pfleiderer. 1992. "Underestimation of Portfolio Insurance and the Crash of October 1987." Review of Financial Studies 5:35-63.

Jovanovic, Boyan. 2006. “Asymmetric Cycles.” Review of Economic Studies 73:145-162.

Kaminsky, Graciela, and Sergio Schmukler. 2008. “Short Run Pain, Long Run Gain: Financial Liberalization and Stock Market Cycles." Review of Finance 12:253-292. 
La Porta, Rafael, Florencio Lopez de Silanes, Andrei Shleifer, and Robert Vishny. 1998. “Law and Finance." Journal of Political Economy 106:1113-1155.

Levine, Ross. 1997. "Financial Development and Economic Growth: Views and Agenda." Journal of Economic Literature 35:688-726.

Levine, Ross, Norman Loayza, and Thorsten Beck. 2000. "Financial Intermediation and Growth: Causality and Causes." Journal of Monetary Economics 46:31-77.

Merton, Robert. 1987. "A Simple Model of Capital Market Equilibrium with Incomplete Information." Journal of Finance 42:483-510.

Neely, Christopher, and David Rapach. 2008. "Real Interest Rate Persistence: Evidence and Implications." Federal Reserve Bank of St. Louis Review 90:609-641.

Porter, Michael, Klaus Schwab, Jeffrey Sachs, Andrew Warner, and Macha Levinson. 1999. Global Competitiveness Report. Edited by World Economic Forum. Oxford University Press.

Townsend, Robert M. 1979. “Optimal Contracts and Competitive Markets with Costly State Verification." Journal of Economic Theory 21:265-293.

Van Nieuwerburgh, Stijn, and Laura Veldkamp. 2006. “Learning Asymmetries in Real Business Cycles." Journal of Monetary Economics 53:753-772.

Veldkamp, Laura. 2005. "Slow Boom, Sudden Crash." Journal of Economic Theory 124:230257.

WDI. 2008. World Development Indicators. World Bank. Online Database.

Welch, Ivo. 1992. "Sequential Sales, Learning, and Cascades." Journal of Finance 47:695-732.

Zeira, Joseph. 1994. "Informational Cycles." Review of Economic Studies 61:31-44.

- 1999. "Informational Overshooting, Booms, and Crashes." Journal of Monetary Economics 43:237-257. 


\section{A Appendix}

\section{A.1 Sample of Countries}

All 100 countries in the sample, based on income classification, are shown in Table 11. Reported skewness corresponds to the period 1960 - 2008.

Table 11: Countries Included in Classification by Income

\begin{tabular}{|c|c|c|c|c|c|}
\hline \multicolumn{6}{|c|}{ LR Skewness (1960-2008) by Income Classification } \\
\hline \multicolumn{6}{|c|}{ Income Group 1 (Richest) } \\
\hline Singapore & -0.64 & Italy & 0.59 & Norway & 1.79 \\
\hline Hong Kong & -0.22 & Japan & 0.60 & Portugal & 2.11 \\
\hline Macao & -0.21 & Slovenia & 0.60 & Sweden & 2.99 \\
\hline Israel & -0.07 & Ireland & 0.76 & Korea & 3.47 \\
\hline Switzerland & -0.04 & Spain & 0.77 & France & 4.30 \\
\hline Belgium & 0.12 & Netherlands & 0.78 & Greece & 4.51 \\
\hline United States & 0.31 & Iceland & 1.20 & Kuwait & 5.50 \\
\hline Canada & 0.43 & Germany & 1.41 & Cyprus & 6.82 \\
\hline Finland & 0.58 & United Kingdom & 1.58 & & \\
\hline \multicolumn{6}{|c|}{ Income Group 2} \\
\hline Chile & -0.50 & Hungary & 0.85 & Brazil & 2.92 \\
\hline Estonia & -0.36 & Romania & 1.03 & Czech Republic & 3.65 \\
\hline Uruguay & -0.30 & Argentina & 1.46 & Poland & 5.70 \\
\hline Slovak Republic & 0.19 & Croatia & 1.48 & Gabon & 6.38 \\
\hline Barbados & 0.69 & Venezuela, Rep. Bol. & 1.73 & & \\
\hline South Africa & 0.80 & Mexico & 1.80 & & \\
\hline \multicolumn{6}{|c|}{ Income Group 3} \\
\hline Latvia & -0.42 & Philippines & 0.22 & Equatorial Guinea & 3.61 \\
\hline Namibia & -0.34 & Sri Lanka & 0.44 & Guatemala & 3.86 \\
\hline Thailand & -0.26 & Swaziland & 0.45 & Botswana & 4.54 \\
\hline Russia & -0.23 & Paraguay & 0.75 & Indonesia & 4.62 \\
\hline Lithuania & -0.14 & Bolivia & 1.14 & Cape Verde & 6.22 \\
\hline Dominican Republic & -0.08 & Jordan & 1.83 & Morocco & 8.14 \\
\hline Colombia & -0.05 & Jamaica & 2.01 & Guyana & 10.25 \\
\hline Grenada & 0.10 & El Salvador & 2.35 & & \\
\hline Peru & 0.20 & Egypt & 2.82 & & \\
\hline \multicolumn{6}{|c|}{ Income Group 4 (Poorest) } \\
\hline Angola & -0.61 & Haiti & 1.09 & Chad & 4.43 \\
\hline Mozambique & -0.52 & Vietnam & 1.95 & Lao People's Dem.Rep & 4.73 \\
\hline Moldova & -0.47 & Rwanda & 2.17 & Congo, Republic of & 4.99 \\
\hline Nigeria & -0.46 & Honduras & 2.64 & Senegal & 5.13 \\
\hline Nicaragua & -0.39 & India & 2.91 & Central African Rep. & 5.73 \\
\hline Kenya & -0.08 & Uganda & 2.95 & Madagascar & 8.01 \\
\hline Armenia & 0.14 & Zambia & 3.22 & Albania & 8.01 \\
\hline Burundi & 0.49 & Tanzania & 3.30 & Ethiopia & 8.44 \\
\hline Lesotho & 0.70 & Tunisia & 3.49 & Bangladesh & 8.80 \\
\hline Solomon Islands & 1.00 & Malawi & 3.91 & Gambia, The & 9.01 \\
\hline Sierra Leone & 1.01 & Cameroon & 4.31 & Mauritania & 10.16 \\
\hline
\end{tabular}


The rest of country classifications are reported in Table 12.

Table 12: Countries Included in Other Classifications

\begin{tabular}{|c|c|}
\hline OECD (23 countries) & Non-OECD Countries (77 countries) \\
\hline $\begin{array}{l}\text { Belgium, Canada, Czech Republic, Finland, France, } \\
\text { Germany, Greece, Hungary, Iceland, Ireland, Italy, } \\
\text { Japan, Korea, Mexico, Netherlands, Norway, } \\
\text { Poland, Portugal, Spain, Sweden, Switzerland, } \\
\text { United Kingdom, United States. }\end{array}$ & $\begin{array}{l}\text { Albania, Angola, Argentina, Armenia, Bangladesh, } \\
\text { Barbados, Bolivia, Botswana, Brazil, Burundi, } \\
\text { Cameroon, Cape Verde, Central African Rep., } \\
\text { Chad, Chile, Hong Kong, Macao, Colombia, Congo, } \\
\text { Croatia, Cyprus, Dominican Republic, Egypt, El } \\
\text { Salvador, Equatorial Guinea, Estonia, Ethiopia, } \\
\text { Gabon, Gambia, Grenada, Guatemala, Guyana, } \\
\text { Haiti, Honduras, India, Indonesia, Israel, Jamaica, } \\
\text { Jordan, Kenya, Kuwait, Lao People's Dem. Rep., } \\
\text { Latvia, Lesotho, Lithuania, Madagascar, Malawi, } \\
\text { Mauritania, Moldova, Morocco, Mozambique, } \\
\text { Namibia, Nicaragua, Nigeria, Paraguay, Peru, } \\
\text { Philippines, Romania, Russia, Rwanda, Senegal, } \\
\text { Sierra Leone, Singapore, Slovak Republic, } \\
\text { Slovenia, Solomon Islands, South Africa, Sri Lanka, } \\
\text { Swaziland, Tanzania, Thailand, Tunisia, Uganda, } \\
\text { Uruguay, Venezuela, Vietnam, Zambia. }\end{array}$ \\
\hline High Contract Enforcement ( 27 countries) & Low Contract Enforcement ( 28 countries) \\
\hline $\begin{array}{l}\text { Argentina, Belgium, Brazil, Canada, Chile, Finland, } \\
\text { France, Germany, Greece, India, Ireland, Israel, } \\
\text { Italy, Japan, Korea, Mexico, Netherlands, Norway, } \\
\text { Portugal, Spain, Sweden, Switzerland, Thailand, } \\
\text { United Kingdom, United States, Uruguay, } \\
\text { Venezuela. }\end{array}$ & $\begin{array}{l}\text { Botswana, Burundi, Cameroon, Cape } \text { Verde, } \\
\text { Central African Rep., Chad, Colombia, Congo, } \\
\text { Equatorial Guinea, Ethiopia, Gabon, Gambia, } \\
\text { Kenya, Lesotho, Madagascar, Malawi, } \\
\text { Mozambique, Namibia, Nigeria, Peru, Philippines, } \\
\text { Sierra Leone, South Africa, Sri Lanka, Swaziland, } \\
\text { Tanzania, Uganda, Zambia. }\end{array}$ \\
\hline Private Bureau (40 countries) & Non-Private Bureau (40 countries) \\
\hline $\begin{array}{l}\text { Argentina, Bolivia, Botswana, Brazil, Canada, } \\
\text { Chile, Hong Kong, Colombia, Czech Republic, El } \\
\text { Salvador, Finland, Germany, Greece, Guatemala, } \\
\text { Hungary, Ireland, Israel, Italy, Japan, Kenya, Korea, } \\
\text { Kuwait, Mexico, Namibia, Netherlands, Norway, } \\
\text { Paraguay, Peru, Philippines, Poland, Portugal, } \\
\text { Singapore, South Africa, Spain, Sweden, } \\
\text { Switzerland, Thailand, United Kingdom, United } \\
\text { States, Uruguay. }\end{array}$ & $\begin{array}{l}\text { Albania, Angola, Armenia, Bangladesh, Belgium, } \\
\text { Burundi, Cameroon, Central African Rep., Chad, } \\
\text { Congo, Croatia, Egypt, Ethiopia, France, Haiti, } \\
\text { Honduras, India, Indonesia, Jamaica, Jordan, Lao } \\
\text { People's Dem. Rep., Latvia, Lesotho, Lithuania, } \\
\text { Madagascar, Malawi, Moldova, Morocco, } \\
\text { Mozambique, Nicaragua, Nigeria, Russia, Sierra } \\
\text { Leone, Slovak Republic, Slovenia, Tanzania, } \\
\text { Uganda, Venezuela, Vietnam, Zambia. }\end{array}$ \\
\hline
\end{tabular}

\section{A.2 Volatility of Lending Rates}

Table 13 shows that it is not possible to distinguish a clear difference among countries in terms of volatility of changes in lending rates, T-bills, or spreads. The model is consistent with the data, since differences in monitoring costs do not deliver any pattern of cross-country differences in lending rate volatility. However, the model fails to match the level of volatility. 
Table 13: Data vs. Estimated Volatility in Changes of Lending Rates

\begin{tabular}{|l|c|c|c|c|}
\hline \multirow{2}{*}{\multicolumn{1}{c|}{$\begin{array}{c}\text { Country } \\
\text { Classification }\end{array}$}} & \multicolumn{4}{c|}{ Volatility (in \% - St. Dev.) } \\
\cline { 2 - 5 } & \multicolumn{3}{|c|}{ Data } & Model \\
\cline { 2 - 5 } & $\begin{array}{c}\text { Lending } \\
\text { Rates }\end{array}$ & $\begin{array}{c}\text { T-Bill } \\
\text { Rates }\end{array}$ & Spread & Spread \\
\hline Income group 1 & 4.3 & 12.6 & 25.8 & $\mathbf{1 . 1}$ \\
Income group 2 & 9.8 & 13.8 & 40.8 & $\mathbf{1 . 0}$ \\
Income group 3 & 5.4 & 11.5 & 32.6 & $\mathbf{0 . 9}$ \\
Income group 4 & 6.1 & 13.0 & 27.4 & $\mathbf{0 . 9}$ \\
\hline OECD & 5.0 & 9.8 & 32.9 & $\mathbf{0 . 9}$ \\
Non-OECD & 6.6 & 13.9 & 29.2 & $\mathbf{0 . 9}$ \\
\hline High contract enforcement & 5.7 & 11.2 & 31.8 & $\mathbf{0 . 9}$ \\
Low contract enforcement & 4.7 & 11.8 & 26.8 & $\mathbf{0 . 8}$ \\
\hline Private bureau & 6.2 & 12.4 & 30.7 & $\mathbf{0 . 7}$ \\
No private bureau & 6.7 & 13.5 & 31.4 & $\mathbf{0 . 7}$ \\
\hline
\end{tabular}

\section{A.3 Robustness on the Skewness Definition}

In the main text, I analyze differences of skewness in log changes of real lending rates across countries, using several classifications related to financial development. Here, I extend the analysis using two alternative approaches to measure skewness.

First, I compute skewness in the distribution of log deviations from a real lending rate trend. For each month, I obtain the difference between the log of real lending rates and the log of the Hodrick-Prescott trend. Table 14 shows that the results using this approach are very similar to those in the main text, hence skewness does not seem to depend on differences of the trend across countries.

Second, the model can be interpreted as a model of skewness in lending spreads rather than a model of skewness in lending rates, since I do not discuss the determination of risk-free interest rates. Table 15 shows cross-country differences in skewness of log changes in lending spreads and log changes in risk-free rates. Differences in lending spread skewness are consistent with those in the main text. Asymmetry seems to be higher among poor, non-OECD countries with low enforcement of contracts. Furthermore, skewness in lending rates is not driven by skewness in risk-free interest rates since T-bill rates are more skewed in developed countries than in developing countries.

An important drawback to use skewness of lending spreads is that the measure of Treasury bill yields in developing countries is not available on a high-quality basis. Hence, the use of spreads to compare developed and developing countries is seriously hindered. This is the main reason I focus directly on analyzing skewness of lending rates in the main text. 
Table 14: Asymmetry on Lending Rates and Financial Development (Using differences in the $\log$ deviation from trend)

\begin{tabular}{|l|c|c|c|}
\hline Country Classification & $1960-1985$ & $1985-2008$ & $1960-2008$ \\
\hline Income group 1 (richest) & 2.55 & -0.09 & $\mathbf{0 . 8 5}$ \\
Income group 2 & 2.59 & 1.80 & $\mathbf{1 . 9 0}$ \\
Income group 3 & 4.12 & 1.93 & $\mathbf{1 . 9 2}$ \\
Income group 4 (poorest) & 4.46 & 2.34 & $\mathbf{2 . 6 3}$ \\
\hline OECD & 2.21 & 1.34 & $\mathbf{2 . 0 7}$ \\
Non-OECD & 4.08 & 1.49 & $\mathbf{1 . 7 1}$ \\
\hline High contract enforcement & 1.93 & 0.68 & $\mathbf{1 . 5 3}$ \\
Low contract enforcement & 3.65 & 2.11 & $\mathbf{2 . 3 4}$ \\
\hline Private bureau & 1.82 & 0.87 & $\mathbf{1 . 0 6}$ \\
No private bureau & 4.82 & 1.86 & $\mathbf{2 . 2 0}$ \\
\hline
\end{tabular}

\begin{tabular}{|l|c|c|c|c|}
\hline Dependent Variable & \multicolumn{2}{|c|}{ All Countries } & \multicolumn{2}{c|}{ Non-African Countries } \\
\cline { 2 - 5 } Lending Rate Skewness & $1960-1985$ & $1985-2008$ & $1960-1985$ & $1985-2008$ \\
\hline \multirow{3}{*}{ Credit to private sector / GDP } & -0.034 & -0.019 & -0.045 & -0.015 \\
& $(0.014)^{* *}$ & $(0.005)^{* * *}$ & $(0.016)^{* * *}$ & $(0.005)^{* * *}$ \\
Constant & 4.44 & 2.29 & 5.23 & 1.93 \\
& $(0.68)^{* * *}$ & $(0.41)^{* * *}$ & $(0.91)^{* * *}$ & $(0.50)^{* * *}$ \\
\hline Observations & 47 & 94 & 31 & 70 \\
\hline
\end{tabular}

Notes: * Significant at $10 \%,{ }^{* *}$ significant at $5 \%$, and ${ }^{* *}$ significant at $1 \%$. Robust standard errors are reported in parentheses. The dependent variable is the skewness measured over the distribution of log changes in monthly lending rates in deviations from Hodrick-Prescott trend, obtained from the IMF's IFS database. Yearly data on credit to the private sector as a percentage of GDP are from the World Bank's WDI database. The simple average per country over the period sample is considered.

Table 15: Asymmetry on Spreads and Risk-free Interest Rates by Country Classification

\begin{tabular}{|l|c|c|}
\hline Country Classification & Spread Skewness & T-Bill Skewness \\
\hline Income group 1 (richest) & -0.03 & 0.59 \\
Income group 2 & -0.22 & 0.58 \\
Income group 3 & 0.38 & 0.69 \\
Income group 4 (poorest) & 0.51 & -0.36 \\
\hline OECD & -0.37 & 0.68 \\
Non-OECD & 0.43 & 0.21 \\
\hline High contract enforcement & -0.19 & 0.58 \\
Low contract enforcement & 0.50 & -0.31 \\
\hline Private bureau & 0.01 & 0.56 \\
No private bureau & 0.27 & -0.01 \\
\hline
\end{tabular}




\section{A.4 Optimal Equilibrium with Stochastic Monitoring}

Proposition 4 In the optimal equilibrium with stochastic monitoring $\left(\gamma_{t} \in[0,1]\right)$ borrowers never lie $\left(z_{i t}=1\right)$ and monitoring probabilities and lending rates are, for all lenders $j$ at time $t$

$$
\begin{aligned}
\gamma_{i t} & = \begin{cases}1 & \text { if } v_{i t}<\frac{1+r+\left(1-\theta_{t}\right) c}{\theta_{t}} \\
\frac{1+r}{\theta_{t} v_{i t}-\left(1-\theta_{t}\right) c} & \text { otherwise }\end{cases} \\
\left(1+\rho_{i t}\right) & = \begin{cases}\frac{1+r+\left(1-\theta_{t}\right) c}{\theta_{t}} & \text { if } v_{i t}<\frac{1+r+\left(1-\theta_{t}\right) c}{\theta_{t}} \\
\frac{(1+r) v_{i t}}{\theta_{t} v_{i t}-\left(1-\theta_{t}\right) c} & \text { otherwise }\end{cases}
\end{aligned}
$$

Entrepreneurs $i$ borrow $\left(b_{i t}=1\right)$ from any lender $j$ whenever

$$
v_{i t} \geq \widetilde{\nu}_{t}=\frac{1+r+w+\left(1-\theta_{t}\right) c}{2 \theta_{t}}+\frac{\sqrt{(1+r+w)^{2}+\left(1-\theta_{t}\right) c\left[2(1+r-w)+\left(1-\theta_{t}\right) c\right]}}{2 \theta_{t}}
$$

Proof. As in the main text, we assume full commitment, which means the lender commits to follow the random strategy $\gamma_{i t}$. Note that the standard debt contract, where $\gamma_{i t}=1$ regardless of $v_{i t}$, is also an equilibrium. However, when $v_{i t}$ is high enough, it is not necessary $\gamma_{i t}=1$ to achieve truth-telling. A lower monitoring probability reduces lending rates maintaining incentives to pay back, which is naturally preferred by borrowers. Borrowers tell the truth if $v_{i t}-\left(1+\rho_{t}\right)>\left(1-\gamma_{t}\right) v_{i t}$, subject to $\gamma_{i t} \leq 1$. The solution is $\gamma_{i t}=\min \left\{\frac{\left(1+\rho_{i t}\right)}{v_{i t}}, 1\right\}$.

From perfect competition, the previous $\gamma_{i t}$ implies that, $\theta_{t}\left(1+\rho_{i t}\right)-\left(1-\theta_{t}\right) c \frac{\left(1+\rho_{i t}\right)}{v_{i t}}=1+r$. Solving first for $1+\rho_{i t}$ and then for $\gamma_{i t}$, gives equations (17) and (18). Given this contract conditional on $v_{i t}$, entrepreneurs borrow if $\theta_{i t} v_{i t}\left[1-\frac{1+r}{\theta_{t} v_{i t}-\left(1-\theta_{t}\right) c}\right] \geq w$. From this equation, comes the cutoff in equation (19).

Four features of this equilibrium are worth noting. First, $\widetilde{\nu}_{t}>\frac{1+r+\left(1-\theta_{t}\right) c}{\theta_{t}}$ for all monitoring costs $c \geq 0$. This means that, effectively, borrowers have a level of $v_{i t}$ such that monitoring costs are given by $\gamma_{i t}=\frac{1+r}{\theta_{t} v_{i t}-\left(1-\theta_{t}\right) c}$, from equation (17), and lending rates are given by $(1+$ $\left.\rho_{i t}\right)=\frac{(1+r) v_{i t}}{\theta_{t} v_{i t}-\left(1-\theta_{t}\right) c}$, from equation (18). Second, if $c=0$ or $\theta_{t}=1$ the unique equilibrium is the standard debt contract with non-stochastic monitoring. Third, cutoffs in the optimal equilibrium are smaller than those under a standard debt contract since lending rates are lower. Finally, the optimal equilibrium generates the same asymmetry implications as the standard debt contract. Monitoring costs still magnify crashes ( $c$ increases levels of lending rates), and beliefs still follow a time-irreversible process that delays recoveries. This proof follows the same logic as the one for Proposition 3. 